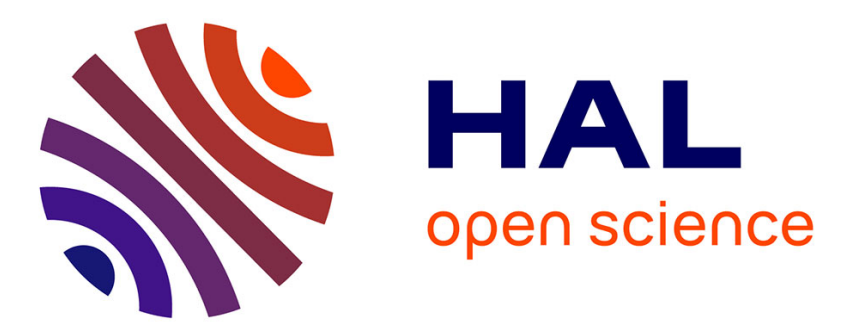

\title{
Cytosine-Cytosinium Dimer Behavior in a Cocrystal with a Decavanadate Anion as a Function of the Temperature
}

\author{
N. Bosnjakovic - Pavlovic, A. Spasojevic-De-Biré
}

\section{- To cite this version:}

N. Bosnjakovic - Pavlovic, A. Spasojevic-De-Biré. Cytosine-Cytosinium Dimer Behavior in a Cocrystal with a Decavanadate Anion as a Function of the Temperature. Journal of Physical Chemistry A, 2010, 114 (39), pp.10664-10675. 10.1021/jp100742g · hal-00582414

\section{HAL Id: hal-00582414 \\ https://hal.science/hal-00582414}

Submitted on 24 Sep 2020

HAL is a multi-disciplinary open access archive for the deposit and dissemination of scientific research documents, whether they are published or not. The documents may come from teaching and research institutions in France or abroad, or from public or private research centers.
L'archive ouverte pluridisciplinaire HAL, est destinée au dépôt et à la diffusion de documents scientifiques de niveau recherche, publiés ou non, émanant des établissements d'enseignement et de recherche français ou étrangers, des laboratoires publics ou privés. 
Cytosine - cytosinium dimer behavior in a co-crystal with a decavanadate anion as a function of the temperature

\section{Nada Bošnjaković-Pavlović ${ }^{1,2}$ and Anne Spasojević-de Biré*1}

${ }^{1}$ Laboratoire Structures, Propriétés et Modélisation des Solides (SPMS), UMR CNRS 8580, Ecole Centrale Paris, Grande Voie des Vignes, 92295 Châtenay-Malabry, France

${ }^{2}$ Faculty of Physical Chemistry, University of Belgrade, P.O. Box 47, 11001 Belgrade, Serbia

* to whom correspondence should be addressed: anne.spasojevic@ecp.fr

Key words : cytosine - cytosinium dimer, decavanadate, X-ray diffraction, charge density, AIM 


\begin{abstract}
We have performed X-ray diffraction measurements on single crystals of $\mathrm{Na}_{3}\left[\mathrm{~V}_{10} \mathrm{O}_{28}\right]$ $\left(\mathrm{C}_{4} \mathrm{~N}_{3} \mathrm{OH}_{5}\right)_{3}\left(\mathrm{C}_{4} \mathrm{~N}_{3} \mathrm{OH}_{6}\right)_{3} \cdot 10 \mathrm{H}_{2} \mathrm{O}$ as a function of the temperature. On cooling, from room temperature to $100 \mathrm{~K}$, we have observed additional peaks well indexed in $\mathrm{P} 1$, while the phase at room temperature crystallizes in $\mathrm{P} \overline{1}$. The molecular structure at $210 \mathrm{~K}$ indicates that the center of inversion is located between two cystosine molecules, formally described with a charge of +0.5 . When heating this crystal to room temperature, and reindexed the structure in $\mathrm{P} \overline{1}$, some peaks remained unindexed. A protonation - deprotonation process gives rise to additional diffraction peaks at lower temperature than $210 \mathrm{~K}$. The triply bridged hydrogen bond cytosine - cytosinum dimer is discussed according to the results of the charge density analysis and topological analysis at $210 \mathrm{~K}$. The structure at $100 \mathrm{~K}$ has been completely solved based on a comparative study with other compounds containing cytosine-cytosinium dimmer. This description could be considered as a reference for such dimmer. It could help for discrimination between cytosine and cytosinium molecule for any new structure containing a cytosine-cytosinium pair and for which the quality doesn't allow a precise determination of the hydrogen localization.
\end{abstract}




\section{Graphical abstract}

We have performed X-ray diffraction measurements on single crystals of $\mathrm{Na}_{3}\left[\mathrm{~V}_{10} \mathrm{O}_{28}\right]$ $\left(\mathrm{C}_{4} \mathrm{~N}_{3} \mathrm{OH}_{5}\right)_{3}\left(\mathrm{C}_{4} \mathrm{~N}_{3} \mathrm{OH}_{6}\right)_{3} \cdot 10 \mathrm{H}_{2} \mathrm{O}$ as a function of the temperature. A protonation deprotonation process gives rise to additional diffraction peaks at lower temperature than 210 $\mathrm{K}$. The triply bridged hydrogen bond cytosine - cytosinium dimer is discussed according to the results of the charge density analysis and topological analysis.

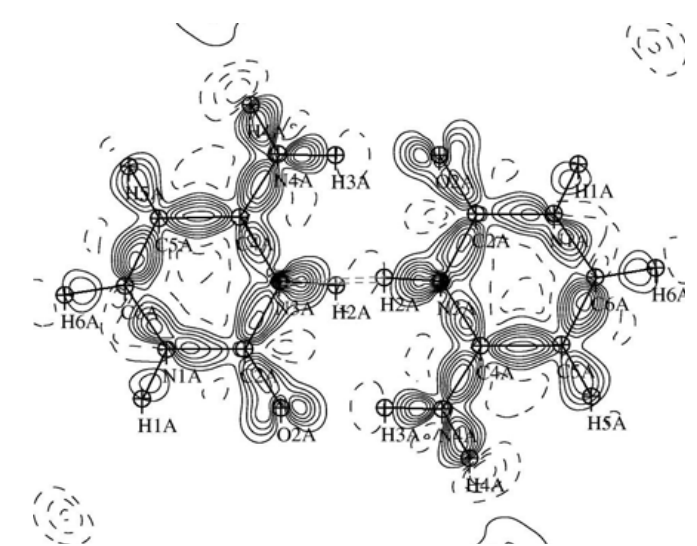

Les paramètres requis sont manquants ou erronés. 


\section{Introduction}

Nucleobases are the parts of deoxyribonucleic acid (DNA) and ribonucleic acid (RNA) that may be involved in pairing. The main ones are cytosine, guanine, adenine (DNA and RNA), thymine (DNA) and uracil (RNA). Nucleobases possess multi hydrogen bonded sites and various tautomers such that they can form abundance of aggregates through hydrogen bonds. Hydrogen bonding between naturally occurring nucleic acid bases of the purine and pyrimidine type is of great biological importance for secondary structures of DNA and RNA [1-3]. Nucleobases exist in solution as equilibrium of two or more tautomers. The relative stability of these tautomers is important for the structure and functioning of DNA and RNA. Specifically, the tautomeric equilibrium between the keto-amino and enol forms of cytosine has been investigated in aqueous solution (scheme 1). Experimental [4-6] and theoretical [714] studies have shown that cytosine exists primarily in the two most stable tautomeric forms, i.e. the aminooxo (canonical) and aminohydroxo forms. Aleman indicates that cytosinium cation is less stable than cytosine using ab initio calculations [15]. Using UV-UV and IR-UV double resonance spectroscopy Nir et al have reported the first spectroscopic data for dimer [16]. Quantum chemical calculations [17-19] of the structure and stability of dimer are reported. From a crystallographic point of view, examination of the Cambridge Structure Database (CSD) [20] give 73 compounds containing cytosine or cytosinium (scheme 1). For 13 compounds, the solid state structures present a cytosinium - cytosine entity is linked with triply hydrogen bonded dimer [21].

Many poloxometalate (POM's) are biologically active. POM's interest recently increased due to their medicinal (antiviral and antitumoral activities) [22-24]. Polyoxovanadate (POV's) interact with biomolecules with various and versatile activity (enzymes inhibitor or activator) [25-26]. Decavanadate is formally a $\left[\mathrm{V}_{10} \mathrm{O}_{28}\right]^{6-}$ polyanion with a cage structure giving rise to 
fascinating supramolecular architectures in the solid state [27-28]. Since the biological properties result from interactions with viral enzymes or with viral cell envelope, the understanding of these interactions at a molecular level is essential for the interpretation and the development of potent compounds with selective enzymatic affinity. In order to get a better understanding on the biochemical interactions of such polyanions, we have synthesized a co-crystal of decavanadate with cytosine. The charge density of $\mathrm{Na}_{3} \quad\left[\mathrm{~V}_{10} \mathrm{O}_{28}\right]$ $\left(\mathrm{C}_{4} \mathrm{~N}_{3} \mathrm{OH}_{5}\right)_{3}\left(\mathrm{C}_{4} \mathrm{~N}_{3} \mathrm{OH}_{6}\right)_{3} \cdot 10 \mathrm{H}_{2} \mathrm{O}$ at $210 \mathrm{~K}$ has been determined and the interactions between the $\left[\mathrm{V}_{10} \mathrm{O}_{28}\right]^{6-}$ anion and its environment have been discussed [29]. In this paper, we will describe the structural behavior of this compound as function of the temperature and focus the discussion on the cytosine - cytosinium dimer according to the result of the charge density at $210 \mathrm{~K}$ which have not been developed in the first paper [29] and the new X-ray crystal structure as determined at $100 \mathrm{~K}$.

\section{Computational method.}

Theoretical calculations have been performed with DFT calculation methods using the Gaussian 03 program package [30]. The coordinates used in calculations are those obtained from the multipole refinement [29]. The calculation of the electrostatic potential have been performed in a vacuum using B3LYP functional with $6-31++G(2 d, 2 p)$.

\section{Experimental}

Crystallographic measurements were carried out on Bruker-SMART three-circle diffractometer equipped with a CCD area detector using MoK $\alpha$ radiation $(\alpha=0.71073 \AA)$ from $300 \mathrm{~K}$ to $100 \mathrm{~K}$, and summarized in Table 1 . The absorption correction was applied 
using SADABS [31]. Data were sorted and merged using SORTAV [32]. The structure was solved by SIR92 [33]. $\mathrm{Na}_{3}\left[\mathrm{~V}_{10} \mathrm{O}_{28}\right]\left(\mathrm{C}_{4} \mathrm{~N}_{3} \mathrm{OH}_{5}\right)_{3} \quad\left(\mathrm{C}_{4} \mathrm{~N}_{3} \mathrm{OH}_{6}\right)_{3} \cdot 10 \mathrm{H}_{2} \mathrm{O}$ crystallizes in the centrosymmetric space group $\mathrm{P} \overline{1}$ at temperature greater than $180 \mathrm{~K}$. All structural calculations (Table 2) were performed by using the SHELXL-97 [34] program of the WINGX software package [35]. Thermal ellipsoid plots were obtained using the program ORTEP3 [36]. Synthesis, crystalization, data collection, data reduction and refinements of the structure at $210 \mathrm{~K}$ have already been described [29]. The methodology used for this structure and some pertinent parameters are given in footnote [37].

\section{Results and discussion}

\section{Diffraction behaviour in cooling and heating}

The following comments underline some experimental steps described in Table 1.

We have tried two ways for cooling the single crystal until $100 \mathrm{~K}$. The first way was an ultra fast freezing, the second way was a very slow cooling speed of $10 \mathrm{~K} / \mathrm{h}$, from $300 \mathrm{~K}$ to $100 \mathrm{~K}$. Before first cooling a room temperature measurement has been done. The experimental conditions and refinement parameters are summarized in table 2. Surprisingly, for the two processes of cooling, the determination of the orientation matrix at $100 \mathrm{~K}$ and the unit cell, gives the same $\mathrm{P} \overline{1}$ space group as at room temperature, but some diffraction peaks remain unindexed in that space group (figure 1d). They were indexed by doubling the unit cell volume and indexing the crystal in the P1 space group. We made a complete data collection at $100 \mathrm{~K}, 1.5$ hour after the stabilization of the temperature. More suprisingly, when we returned at room temperature, and reindexed the crystal in the previous space group and orientation matrix determined before the cooling, some peaks remained unindexed (figure $1 \mathrm{~b}$ ). We decided to go back slowly at $210 \mathrm{~K}$ and performed a high resolution data collection for a 
charge density study, where we have still not observed additional peaks during the first cooling. This temperature seems sufficiently low to minimize the effect of the temperature on the $U_{\mathrm{ij}}$ parameters and sufficiently high to avoid problems of additional peaks.

The refinements of the structure have been done for the three temperatures in the $\mathrm{P} \overline{1}$ space group at $300 \mathrm{~K}$ and $210 \mathrm{~K}$ and in the $\mathrm{P} 1$ space group at $100 \mathrm{~K}$ (table 2). At $100 \mathrm{~K}$ in the non centrosymmetric space group the center of inversion is suppressed, leading to an asymmetric unit including 12 molecules of cytosine, 2 molecules of decavanadate, 6 atoms of sodium, and 40 water molecules. Due to the high number of parameters, we were not able to localize hydrogen atoms from the Fourier difference maps. At $210 \mathrm{~K}$, a multipole refinement according to Hansen-Coppens model [38] has been done on crystal 2 and crystal 3 [37]. The decavanadate environment has been described at $210 \mathrm{~K}$ [29]. In order to interpret the change between the high and the low temperature phase, we have to go back deeply in the structure at $100 \mathrm{~K}$ and $210 \mathrm{~K}$ focusing on the dimer behaviour.

Molecular structure, crystal packing, deformation maps, topology of the total density, net atomic charges and electrostatic potential at $210 \mathrm{~K}$ of the cytosine-cytosinium dimers

The asymmetric unit of the title compound contains three different molecules of cytosine. The cytosine $\mathrm{C}$ is not protonated and is neutral. The cytosinium B is protonated, and hydrogen atom $\mathrm{H} 2 \mathrm{~b}$ is bonded to $\mathrm{N} 3 \mathrm{~b}$ leading to charge of +1 for the molecule. The cytosinium $\mathrm{A}$ is protonated, a half of hydrogen atoms $\mathrm{H} 2 \mathrm{a}$ is bonded to $\mathrm{N} 3 \mathrm{a}$, with charge +0.5 . This hydrogen lies on the crystallographic center of symmetry (Figure 2). Some interatomic distances in cytosine $\mathrm{C}(\mathrm{C} 2 \mathrm{c}-\mathrm{O} 2 \mathrm{c}, \mathrm{C} 6 \mathrm{c}-\mathrm{N} 1 \mathrm{c})$ deviate significantly from the corresponding distances in cytosinium A and cytosinium B. Cytosine C presents high Uij values, mainly located on N1c and C6c. These high Uij have been observed on the two crystal for which high resolution Xray diffraction have been performed. The distances for protonated cytosinium $\mathrm{B}$ (with $\mathrm{H}$ atom 
on $\mathrm{N} 3 \mathrm{~b}$ ) has been compared with corresponding molecules of cytosinium, retrieved from CSD [20]; 31 data extracted from 25 different structures containing cytosinium molecule, with agreement factor less than 0.05 [43]. The same study has been done for cytosine $\mathrm{C}$ (without $\mathrm{H}$ atom on $\mathrm{N} 3 \mathrm{c}$ ); 5 data extracted from 5 different cytosine structures, with agreement factor less than 0.05 [44] (table 3). Distances for cytosine A have not been taken into account, the symmetry center have implied that the structure have been modelized with half of a hydrogen atom on N3a. Table 3 shows that our distances are in good agreement with those from literature data. Most of them are in the range from minimum to maximum distance for selected bonds.

The geometry is quite similar to those found in previously reported structures of cytosine. As it shown, in previous studies [45-47], the protonation of the cytosine molecule induced a modification of the bond length. Not unexpectedly, the N3-C bonds of the protonated N3b nitrogen atom are slightly longer than those of the nitrogen atom N3c that acts as hydrogen acceptor. Accordingly, both the N3b-C4b and N3b-N2b bonds are longer than N3c-C4c and $\mathrm{N} 3 \mathrm{c}-\mathrm{N} 2 \mathrm{c}$ (1.354(1) versus 1.351(1) $\AA$ and 1.365(1) $\AA$ versus 1.357 (1) $\AA$ ), respectively. Furthermore, the angle $\mathrm{C} 2-\mathrm{N} 3-\mathrm{C} 4$ at protonated $\mathrm{N} 3 \mathrm{~b}$ is slightly greater $\left(0.2^{\circ}\right)$ than those of the non-protonated $\mathrm{N} 3 \mathrm{c}\left(122.26^{\circ}\right.$ versus $\left.122.01^{\circ}\right)$. Thus, as expected, the difference between the angle in the protonated (cytosinium) and the non-protonated molecule (cytosine) are sensitive to the protonation $\left(\Delta_{\mathrm{B}-} \mathrm{C}(\mathrm{N} 3-\mathrm{C} 4-\mathrm{C} 5)=-1.5^{\circ}\right)$ and $\left.\Delta_{\mathrm{B}-\mathrm{C}} \mathrm{C}(\mathrm{N} 4-\mathrm{C} 4-\mathrm{C} 5)=+1.6^{\circ}\right)$. All these experimental values exhibit the same trend founded in previous theoretical DFT study [46] and experimental study works $[45,47]$.

Two molecules of cytosine A (figure 2a) are connected over the three strong hydrogen bonds

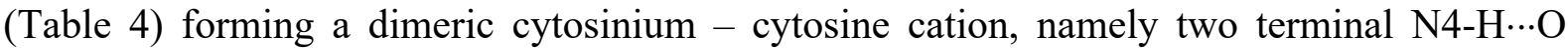
$\left(\mathrm{N} 4 \mathrm{a} \cdots \mathrm{O} 2 \mathrm{a}^{(\mathrm{i})}=2.841(1) \AA\right.$ and $\left.\mathrm{N} 4 \mathrm{a}-\mathrm{H} 3 \mathrm{a}-\mathrm{O} 2 \mathrm{a}^{(\mathrm{i})}=177.12(6)^{\circ}\right)$ and a central $\mathrm{N} 3-\mathrm{H} \cdots \mathrm{N} 3$ $\left(\mathrm{N} 3 \mathrm{a} \cdots \mathrm{N} 3 \mathrm{a}^{(\mathrm{i})}=2.838(2) \AA\right.$ and N3a-H2a-N3a $\mathrm{a}^{(\mathrm{i})}=167.72(2)^{\circ}$ (figure 2a). In this dimeric cation, 
the terminal N4a-H3a $\cdots$ O2a hydrogen bonds are identical. The hydrogen atom of the central N3a-H2a-N3a hydrogen bond is disordered over two equally occupied positions related by an inversion center. Two molecules of cytosinium $\mathrm{B}$ and $\mathrm{C}$ are connected via three strong hydrogen bonds. The central hydrogen bond is $\mathrm{N} 3 \mathrm{~b} \cdots \mathrm{N} 3 \mathrm{c}\left(\mathrm{N} 3 \mathrm{~b} \cdots \mathrm{N} 3 \mathrm{c}^{(\mathrm{ii})}=2.816(1) \AA\right.$ and $\mathrm{N} 3 \mathrm{~b}-\mathrm{H} 2 \mathrm{~b}-\mathrm{N} 3 \mathrm{c}^{(\mathrm{ii})}=173.39(5)^{\circ}$ (figure $2 \mathrm{~b}$ ). The two terminal N4-H3 $\cdots \mathrm{O} 2$ hydrogen bonds are different, a weaker $\left(\mathrm{N} 4 \mathrm{~b} \cdots \mathrm{O} 2 \mathrm{c}^{(\mathrm{ii})}=2.874(2) \AA\right.$ ) and a stronger one $\left.\mathrm{N} 4 \mathrm{c} \cdots \mathrm{O} 2 \mathrm{~b}^{(\mathrm{ii})}=2.756(1) \AA\right)$. This is expected because protonation implies to different bond distances and bond angles (table 3). We have observed a difference in the hydrogen bond in cytosine A, B and C, in the N1 - C6 region. The hydrogen bonds which exist in cytosine $\mathrm{C}\left(\mathrm{C} 5 \mathrm{c}-\mathrm{H} 5 \mathrm{c} \cdots \mathrm{O} 22^{(\mathrm{iii})}\right.$, N1c$\mathrm{H} 1 \mathrm{c} . . \mathrm{O} 2 \mathrm{w})$ are longer than those present in cytosinium $\mathrm{B}$ and $\mathrm{A}(\mathrm{H} \ldots \mathrm{O}=2.6819(5)$ versus 2.0702(6) and $\mathrm{H} \ldots \mathrm{O}=2.2430(7)$ and 2.288(1) versus $1.7519(7)$ and 1.7006(7), respectively. Hydrogen bonds which exist in cytosine $\mathrm{C}\left(\mathrm{C} 5 \mathrm{c}-\mathrm{H} 5 \mathrm{c} \cdot \mathrm{OO} 22^{(\mathrm{iii})}, \mathrm{N} 1 \mathrm{c}-\mathrm{H} 1 \mathrm{c} \cdots \mathrm{O} 2 \mathrm{w}\right)$ are longer than in cytosine $\mathrm{B}$ and $\mathrm{C}$ (table 4$)$. The summation of $\mathrm{d}(\mathrm{H} . . . \mathrm{A})$ interatomic distances for each cytosine, gives a quantification of the strength of the hydrogen bond network and clearly indicates that cytosine $\mathrm{C}$ is not stabilized with strong hydrogen bond, compared to the two other cytosine molecules. This in agreement with the thermal parameters, which are greater for cytosine $\mathrm{C}$ and then coherent with the fact that these high $\mathrm{U}_{\mathrm{ij}}$ were observed for multipole refinemnent at $210 \mathrm{~K}$ of crystal 2 and 3 . The hemiprotonated cytosine dimers with triple hydrogen bonds reported in CSD [21] present the both cytosine-cytosinium entities. The B-C type exists is seven structure [21a,b,d,e,f,g,h] while the A-A type has been observed in six structures $[21 \mathrm{c}, \mathrm{e}, \mathrm{i}, \mathrm{j}, \mathrm{k}]$.

The deformation density of the cytosine (figure 3) illustrates the covalent bonding between adjacent carbon atoms [37] with the maxima of $0.6-0.9 \mathrm{e} \AA^{-3}$, or carbon and nitrogen atoms, with the maxima of $0.5-0.9 \mathrm{e}^{-3}$. These features exhibit pronounced electron density accumulations, usually attributed to covalent bonding. Figures 3 show large electron density 
peaks between atoms and those corresponding to lone pair density peaks of $\mathrm{O} 2$ and $\mathrm{N} 3 \mathrm{c}$ atoms. If we compare $\mathrm{N} 3 \mathrm{a}, \mathrm{N} 3 \mathrm{~b}$ and $\mathrm{N} 3 \mathrm{c}$, static density maps indicate very distinctly that $\mathrm{N} 3 \mathrm{a}$ and $\mathrm{N} 3 \mathrm{~b}$ are connected to the $\mathrm{H} 2$ hydrogen atoms. We can also see the density peaks, which are significantly displaced toward the $\mathrm{N} 3$, due to the electronegativity of this atom. In the vicinity of the $\mathrm{N} 3 \mathrm{c}$ atom (figure 3 ), the nonbonding density corresponds to the lone paire. One can compare these features with previous experimental or theoretical deformation density. The same behaviour around the $\mathrm{N} 3$ atom have been found in the previous theoretical $4-31 \mathrm{G}^{* *}$ calculation [48] and experimental results [49] or in experimental and theoretical $6-31 \mathrm{G}^{* *}$ study on a cytosine monohydrate [50]. Eisenstein [49] was the first who reports an experimental charge density study on the cytosine monohydrate in 1988. She did an ab initio theoretical calculation with $4-31 \mathrm{G}$ and $4-31 \mathrm{G}^{* *}$ bases because previous STO-3G study [51] was not satisfactory. She has shown that charge density maps from $4-31 G^{* *}$ results, is much closer to the experimental map, than to maps computed with lower bases. Our experimental static deformation density of cytosine fits very well with corresponding theoretical $4-31 \mathrm{G}^{* *}$ deformation density in positions, shapes and heights of most peaks (figure 3). Eisenstein has also reported that the difference between the experimental and $4-31 \mathrm{G}^{* *}$ maps occurs in nonbonding regions, where the experimental density peaks are lower. In both studies, it has been found a non-bonding density around the $\mathrm{N} 3$ and $\mathrm{O} 2 \mathrm{~b}$ atoms corresponding to their lone pairs. The N-H...N hydrogen bonds serve to link two cytosine molecules in order to form a dimmer (figure 3). The nitrogen lone pair is clearly engaged in the hydrogen bond in the case of the BC dimer, while the A-A model, using half of an hydrogen does not allowed a real observation of the density of this bond.

The topological parameters of the electron density for the $(3,-1)$ bond critical points $(\mathrm{BCP})$ [37] in cytosine molecules are given in table 5. As expected, the BCP of the heteronuclear C$\mathrm{N}$ and $\mathrm{C}-\mathrm{O}$ bonds, is always located closer to the less electronegative carbon atom $\left(\mathrm{d}_{1}<\mathrm{d}_{2}\right)$. 
The $\rho\left(r_{\mathrm{cp}}\right)$ and $\nabla^{2} \rho\left(\mathrm{r}_{\mathrm{cp}}\right)$ values $\left(\nabla^{2} \rho\left(\mathrm{r}_{\mathrm{cp}}\right)<0\right.$ corresponding to a shared-shell interaction) at the bond critical point are characteristic of covalent bonds; a shorter bond corresponds to a higher density and a more negative Laplacian. The highest absolute value of Laplacian is found for the $\mathrm{C}-\mathrm{O}$ bond, which corresponds the shortest distance. The bond belonging to the ring have higher electron density at the bond critical point with an average value of $2.1 \mathrm{e}^{-3}$, while ellipticities at the BCPs vary from $0.06-0.42$. These values indicate the $\pi$ character of these bonds. The $\rho\left(r_{c}\right)$ values range from $1.78 \mathrm{e}^{-3}$ for $\mathrm{C}-\mathrm{C}$ bond to the relative high value of $2.84 \mathrm{e}^{-3}$ for C-O. Inspection of table 6 indicates that the two experimental works [51] and theoretical using $6-31 \mathrm{G}^{* *}$ basis set [50] give topological parameters of the covalent bonds in the cytosine molecule which generally agree well. The agreement is even quantitative.

The $\kappa$ coefficients and experimental atomic net charges are listed in table 7 . We have found a negative charge for all $\mathrm{O}$ atoms ranging from $-0.23(6) e$ to $-0.46(7) e$ and a $\kappa$ parameter going from $1.01 e$ (slightly contracted electron density) to $0.948 e$ (slightly expanded electron density). All $\mathrm{N}$ atoms carry a negative charge ranging from -0.26(8) $e$ to $-0.87(8) e$ and a positive charge on most of the carbon atoms, except for the $\mathrm{C} 5$ atom in all three cytosine. This carbon is between two carbons ( $\mathrm{C} 4$ and $\mathrm{C} 6)$, which are connected with the most negative nitrogen atoms. The $\mathrm{H}$ atoms are all positively charged. However, those attached to $\mathrm{N}$ or $\mathrm{O}$ atoms $(\mathrm{H} 1, \mathrm{H} 2, \mathrm{H} 3, \mathrm{H} 4)$ possess a significantly more positive charge than the $\mathrm{H}$ atoms (H5 and H6) connected to a carbon atom. This trend is similar to results, which have been found previously reported in experimental studies $[49,52]$ and theoretical computations [48] for the cytosine molecule. However, the absolute values obtained experimentally for the cytosine molecule are generally smaller that the theoretical values. A large number of the differences between the experimental and theoretical results could be attributed to hydrogen bonding. Thus, the experimental charges of the hydrogen-bonding acceptors $\mathrm{O} 2$ are less negative than 
theoretical values. The experimental charges for $\mathrm{H} 3$ and $\mathrm{H} 4$ are lower than the theoretical value as expected because they are involved in strong hydrogen bonds. For H5 and H6, which participate only in weak hydrogen bond, the difference between theory and experimental is smaller.

Figure 4 shows the theoretical and experimental electrostatic potential (EP) projected on the 3D isodensity surface $\left(0.007 \mathrm{eA}^{-3}\right)$ of the cytosine molecules and the two dimers. The most negative value is founded in the vicinity of $\mathrm{O} 2 \mathrm{c}$ atom (figure $4 \mathrm{a}$ ). The deepest minimum of electrostatic potential is found close to the $\mathrm{O} 2 \mathrm{a}$ oxygen atom $\left(-0.002 \mathrm{eA}^{-1}\right)$. The second deepest minimum is located in the vicinity of $\mathrm{N} 3 \mathrm{a}\left(\mathrm{eA}^{-1}\right)$. In both molecules $(\mathrm{A}$ and $\mathrm{B})$, the vicinity of the hydrogen atom $\mathrm{H} 4$ and $\mathrm{H} 5$ display a minimum electrostatic potential value (figure $4 \mathrm{~b}$ and $4 \mathrm{c}$ ). For cytosine $\mathrm{C}$ the blue region correspond to $0.42 \mathrm{eA}^{-1}$ and the red value to $-0.45 \mathrm{eA}^{-1}$. The deepest minimum of EP is found close to the $\mathrm{O} 2 \mathrm{c}$ oxygen atoms $\left(-0.45 \mathrm{eA}^{-1}\right)$ and around $\mathrm{N} 3 \mathrm{c}\left(-0.28 \mathrm{eA}^{-1}\right)$. It means, that there is an extensive electronegative region around $\mathrm{O} 2$ and N3 and an electropositive region around the N4 amino group and C5. Similar features were also observed $[50,52]$. The EP projected on the cytosinium - cytosine dimmer surface $\mathrm{BC}$ dimer is given in Figure $4 \mathrm{~d}$ to $4 \mathrm{~g}$. The differences observed between the experimental and theoretical values are due to the crystal packing effect. The theoretical calculations have been performed in the gas phase while the experimental plot represent the results at the molecule level extracted from the crystal. The differences observed between figure $4 \mathrm{f}$ and $4 \mathrm{~g}$ are due to the hydrogen bond of $\mathrm{O} 2 \mathrm{c}$ connected to the water molecule $\mathrm{O} 2 \mathrm{c} . . \mathrm{H} 3 \mathrm{wO}_{3} \mathrm{w}$ which is not in the B-C plane. Such a dissymmetry has already been observed in quite similar crystal packing of a salycylaldehyde thiosemicarbazone compound [53]. The H...O interatomic values (figure 4f) are generally coherent with the EP, i.e. a highest positive EP value on the molecular surface corresponds to a shorter H...O distance except for the C6-H6...O. 
The structure at $100 \mathrm{~K}$, solved in the P1 space group, shows six dimers in the asymmetric unit instead of three at higher temperature. he difference between the low and the high temperature structure lie in the lost of the symmetry center between the two cytosine A, and the unit cell determine in $\mathrm{P} 1$ consists in a complicated transformation from the centrosymmetric space group. The quality of the structure at $100 \mathrm{~K}$ does not allow a determination of the hydrogen positions. Therefore, an indirect determination has been done in two steps.

The first step consists in an examination of the crystal packing in order to determinate from which cytosine types (A, B or $\mathrm{C}$ ) are originated the twelve cytosine molecules at low temperature. Table 8 , summarizes in a simplified nomenclature the crystal packing of the structures at 210 and $100 \mathrm{~K}$ while figure 5 presents the cytosine - cytosinium interactions in the 6 dimers. In order to discriminate between the initial A-A or B-C dimers, one have to observed the $\mathrm{O} 2$ cytosine atom. In the case of an $\mathrm{O} 2 \mathrm{~b}$ or $\mathrm{O} 2 \mathrm{c}$ the oxygen is linked to a water molecule, while the $\mathrm{O} 2 \mathrm{a}$ takes place to the coordination polyhedra of the sodium atom (figure 5). The assignation of the original cytosine from the B-C dimer could be easily done by looking at the hydrogen bond connected to the C5 atom. A terminal decavanadate oxygen $(\mathrm{O} 1 \mathrm{x})$ is linked to the cytosine $\mathrm{B}$ while it is linked to a O2x oxygen type in the case of the cytosinium C. According to this table, we can indicate in the line "assignation" a letter indicating from which type of cytosine (A, B or $\mathrm{C}$ ) the dimer corresponds in the high temperature structure.

The second step consists in the determination of the real type of the cytosine $(\mathrm{B}, \mathrm{C}$ or $\mathrm{A})$ at $100 \mathrm{~K}$. That can be done through the observation of the angles around the C4 and the N3 atoms. The difference between the different angles from B-C is reported in Table 9. The sign 
and the absolute value of these differences help in the discrimination between a cytosine $\mathrm{C}$ and a cytosinium B molecule, despite the fact that there is no hydrogen atom determination. In case of cytosine of A type (a proton in equilibrium between the two molecules of the dimer), one can assume that the differences has to be the lowest. These observations imply the assignation (A, B, C type) of the different cytosine molecules (last line of table 8). Some comments have to be done from observation of Table 9: i) the trend clearly indicates that the higher values of the parameter reported here concerned the pure cytosine-cytosinium dimer while the lowest values concerned the intermediate situation (A-A dimers); ii) the values obtained at 300 or $210 \mathrm{~K}$ seems to be abnormally small, but it is due to a better determination of the nucleus position from a charge density study [55-56]. Therefore one can clearly assign the cytosine type to the twelve cytosine of the asymmetric unit (table 9). Four dimers conserve the same type from their originated situation at $210 \mathrm{~K}$ and the last two change.

Back to the interpretation of the behavior of the single crystal in heating and cooling under Xray diffraction

The hydrogen atom is statistically equally shared between the two cytosine at high temperature inducing that the X-ray "see" in average half an hydrogen at the position determined at $300 \mathrm{~K}$ and $210 \mathrm{~K}$. At these high temperatures a dynamic of proton exchange exists, one can say that the proton can "jump" between the two molecules forming for a considered molecule alternatively a cytosine and a cytosinium molecule leading to a symmetry center on the middle of the distance N...N (Figure 4d). At low temperature, this dynamic is blocked, and this proton is "freeze" on one cytosine, leading to the suppression of the inversion center and the doubling of the unit cell volume. It means that the X-ray "see" one hydrogen atom which is located on the one cytosine. The dimer type is conserved for four 
dimers and changed for two. In heating the proton dynamic exists, but it is not any more perfectly statistically distributed, that means that the proton could not be modelized at the middle of the N...N distance. This is not-reversible dynamic cytosine - cytosinium conversion, which is responsible of the additional non-indexed peaks at room temperature after a cooling.

This conversion has been extensively studied due to the fact that the base-base interactions play an important role in the DNA structure. For example, ab initio calculations [19] of different cytosine dimers lead to an electronic dissociation energy of $15.7 \mathrm{kcal} / \mathrm{mole}(5510$ $\mathrm{cm}^{-1}$ ) by Nir while Sponer et al [17] has obtained $20.0 \mathrm{kcal} / \mathrm{mole}$. The quantum chemical calculation on the DFT level of theory [46] show that the interaction energy was calculated to be $42.4 \mathrm{~K} \mathrm{cal} / \mathrm{mole}$ and revealed a high stability of the hydrogen bond in a methylcytosine methylcytosinium dimer.

\section{Conclusion}

During the crystal cooling, below $200 \mathrm{~K}$, we have observed a phase transition in the [ $\mathrm{V}_{10} \mathrm{O}_{28}$ ] $\left(\mathrm{C}_{4} \mathrm{~N}_{3} \mathrm{OH}_{5}\right)_{3}\left(\mathrm{C}_{4} \mathrm{~N}_{3} \mathrm{OH}_{6}\right)_{3} \cdot 10 \mathrm{H}_{2} \mathrm{O}$. According to the precise description of the cytosine cystosinium dimer at $210 \mathrm{~K}$, from charge density results, we have established that the main structural change was the suppression on the inversion center between the two molecules of cytosine. This is this not-reversible dynamic cytosine - cytosinium conversion, which is responsible of the additional non-indexed peaks at room temperature after a cooling. Besides this explanation concerning the title compound, Table 9, could be used as a guide for assignation of the proton localization in cytosine-cytosinium dimmer, in the case where the hydrogen is not clearly detectable from the diffraction study. 


\section{Acknowledgements}

This paper is a part of a join $\mathrm{PhD}$ thesis between the University of Belgrade, Faculty of Physical Chemistry and Ecole Centrale Paris. The authors would thank the French foreign Minister for a COCOOP support on this project. The authors would thank also Pr Nour Eddine Ghermani (UMR 8580, Ecole Centrale Paris, and UMR 8612, Université Paris-Sud) for constructive discussion, Dr Blandine Courcot (present address School of Chemistry, University of Sydney, 2006 NSW, Australia) for theoretical calculations and Pr. Joao Pessoa for giving us single crystals. NB-P would thank the Ministry of Science and Technological Development of the Republic of Serbia (Project 142047).

\section{Supporting Information Available}

Tables S1 and S2 are presented as Supplementary material. This information is available free of charge via the Internet at http://pubs.acs.org. 


\section{References}

[1] Muller-Dethlefs, K.; Hobza, P. Noncovalent interactions: A challenge for experiment and theory. Chem. Rev. 2000, 100, 143-167.

[2] Desfrancois, C.; Carles, S.; Schermann, J. P. Weakly Bound Clusters of Biological Interest. Chem. Rev. 2000, 100, 3943-3962.

[3] Kool, E.T. Hydrogen bonding, base stacking, and steric effects in DNA replication. Annu. Rev. biophis. Biomol. Struct. 2001, 30, 1-22.

[4] Nowak, M. J.; Lapinski L.; Fulara, J. Matrix isolation studies of cytosine: The separation of the infrared spectra of cytosine tautomers Spectrochim. Acta 1989, 45A, 229-242.

[5] Gould, I.R.; Vincent, M.A.; Hiller, I. H.; Lapinski L.; Nowak, A new theoretical prediction of the infrared spectra of cytosine tautomers J. Spectrochim. Act 1992, A48, 811.

[6] Jaworski, A.; Szczesniak, M.; Szczepaniak, K.; Kubulat, K.; Person, W. B. Infrared spectra and tautomerism of 5-fluorocytosine, 5-bromocytosine and 5-iodocytosine. Matrix isolation and theoretical ab initio studies. J. Mol. Struct. 1990, 223, 63-92.

[7] Kobayashi, R. A CCSD(T) Study of the Relative Stabilities of Cytosine Tautomers. J. Phys. Chem. A 1998, 102, 10813-10817.

[8] Les, A.; Adamowicz, L.; Bartlett, R.J. Relative stability of cytosine tautomers with the coupled cluster method and first-order correlation orbitals. J. Phys. Chem. 1989, 93, 40014005 .

[9] Gorb, L.; Podolyan, Y.; Leszczynski, J. A theoretical investigation of tautomeric equilibria and proton transfer in isolated and monohydrated cytosine and isocytosine molecules. J. Mol. Struct. (Theochem) 1999, 487, 47-55.

[10] Trygubenko, S. A.; Bogdan, T. V.; Rueda, M.; Orozsco, M.; Luque, F. J.; Šponer, J.; Slaviček, P.; Hobza, P. Correlated ab initio study of nucleic acid bases and their tautomers in 
the gas phase, in a microhydrated environment and in aqueous solution. Phys. Chem. Chem. Phys. 2002, 4, 4192-4203.

[11] Gorb, L.; Leszczynski, J. Intramolecular Proton Transfer in Monohydrated Tautomers of Cytosine: An Ab Initio Post-Hartree-Fock Study. Int. J. Quant. Chem. 1998, 70, 855-862.

[12] Hall, R. J.; Burton, N. A.; Hillier, I. H.; Young, P. E. Tautomeric equilibria in 2hydroxypyridine and in cytosine. An assessment of density functional methods, including gradient corrections. Chemical Physics Letters 1994, 220, 129-132.

[13] Russo N.; Sicilla, E.; Toscano, M.; Grand, A. Theoretical prediction of nuclear quadrupole coupling constants of DNA and RNA nucleic acid bases J. Mol. Struct. 2001, 563$564,125-134$.

[14] Delchev V.; Nenkova, M. Theoretical Modeling of the Ground State Intramolecular Proton Transfer in Cytosine: DFT Level Study. Acta Chim. Slo. 2008, 55, 132-137.

[15] Aleman, C. The keto-amino/enol tautomerism of cytosine in aqueous solution. A theoretical study using combined discrete/self-consistent reaction field models. Chemical Physics 2000, 253, 13-19.

[16] Nir, E.; Plützer, C.; Kleinermanns, K.;de Vries, M. Properties of isolated DNA bases, base pairs and nucleosides examined by laser spectroscopy Eur. Phys. J. D. 2002, 20, $317-$ 329.

[17] Šponer, J.; Leszczynski, J.; Hobza, P. Base stacking in cytosine dimer. A comparison of correlated ab initio calculations with three empirical potential models and density functional theory calculations. J. Comput. Chem. 2001, 17, 841-850.

[18] Kabelac M.; Hobza, P. Potential energy and free energy surfaces of all ten canonical and methylated nucleic acid base pairs: Molecular dynamics and quantum chemical ab initio studies J. Phys. Chem. B. 2001, 105, 5804-5817. 
[19] Nir, E.; Hunig, I.; Kleinermanns, K.; de Vries, M. The nucleobase cytosine and the cytosine dimer investigated by double resonance laser spectroscopy and ab initio calculations. Phys. Chem. Chem. Phys. 2003, 5, 47804785.

[20] Allen, F.H. The Cambridge Structural Database: a quarter of a million crystal structures and rising. Acta Crystallogr. 2002, B58, 380-388.

[21] a) Tamura, C.; Sato S.; Hata, T. Studies on intermolecular complex-formation .4. Crystal-structure of cytosine-resorcylic acid 2 - 1 complex monohydrate Bull. Chem. Soc. Jpn. 1973, 46, 2388-2394. b) Fujinami, F.; Ogawa, K.; Arakawa, K.; Shirotake, S.; Fujii S.; Tomita, K. Structure of the complex cytosinium hemitetrachlorozincate-cytosine Acta Crystallogr. Sect. B: Struct. Crystallogr. Cryst. Chem. 1979, 35, 968-970. c) Gdaniec, M.; Brycki B.; Szafran, M. Crystal and molecular-structure of cytosine hemitrichloroacetate $J$. Chem. Soc. Perkin Trans. 1988, 2, 1775-1779. d) Salam M..A.; Aoki, K. Interligand interactions affecting specific metal bonding to nucleic acid bases: the tripodal nitrilotriacetato (nta) ligand-system. Crystal structures of [(nta)(adeninium)(aqua)nickel(II)] hydrate, $\quad[($ nta)(diagua)nickel(II) $]$ center $\quad \operatorname{dot}($ cytosinium) $\quad$ hydrate, $\quad$ and [(nta)(diaqua)nickel(II)]center $\operatorname{dot}($ cytosinium)center dot(cytosine)center dot hydrate Inorg. Chim. Acta 2000, 311, 15-24. e) Perumalla, S.R.; Suresh E.; Pedireddi,V.R. Nucleobases in molecular recognition: Molecular adducts of adenine and cytosine with $\mathrm{COOH}$ functional groups Angew. Chem. Int. Ed. 2005, 44, 7752-7757. f) Bancu, L.; Bourosh, P.; Jitaru, I.; Siminov Yu A.; Lipkowski, J. Synthesis and structural characterization of a new cadmium complex with cytosine Rev. Roum. Chim. 2006, 51, 397-401. g) Armentano, D.; De Munno G.; Rossi, R. The counterion as a useful tool to obtain complexes of cytosine with alkali metal ions New J. Chem. 2006, 30, 13-17. h) Murata T.; Saito, G. Properties of reaction products between cytosine and $\mathrm{F}(4) \mathrm{TCNQ}$ in $\mathrm{MeOH}$ : Two hemiprotonated cytosine salts with F(4)TCNQ radical anion and methoxy adduct anion Chem. Lett. 2006, 35, 1342-1343. i) 
Murata, T.; Nishimura K.; Saito, G. Organic conductor based on nucleobase: Structural and electronic properties of a charge-transfer solid composed of TCNQ anion radical and hemiprotonated cytosine Mol. Cryst. Liq. Cryst. Sci. Technol. Sect.A 2007, 466, 101-112. j) Murata, T.; Saito, G.; Nishimura,K.; Enomoto, Y.; Honda, G.; Shimizu, Y.; Matsui, S.; Sakata, M.; Drozdova O.O.; Yakushi, K. Complex formation between a nucleobase and tetracyanoquinodimethane derivatives: Crystal structures and transport properties of chargetransfer solids of cytosine Bull. Chem. Soc. Jpn. 2008, 81, 331-344.

[22] Pope, M. T.; Müller, A. (eds.), Polyoxometalates: From Platonic Solids to AntiRetroviral Activity, Kluwer Academic Publishers, Dordrecht, The Netherlands, 1994

[23] Müller, A.; Reuter, H.; Dillinger, S. Supramolecular Inorganic Chemistry: Small Guests in Small and Large Hosts. Angew. Chem. Int. Ed. Engl. 1995, 34, 2328-2361.

[24] Pope, M.T.; Müller, A. (eds.), Polyoxometallate Chemistry: From Topology via SelfAssembling to Applications, Kluwer Academic Publishers, Dordrecht, The Netherlands, 2001 [25] Aureliano, M.; Crans, D. C. Decavanadate $\left(\mathrm{V}_{10} \mathrm{O}_{28}\right)^{6-}$ and oxovanadates: Oxometalates with many biological activities. J. Inorg. Biochem. 2009, 103, 536-546.

[26] Krstić, D.; Čolović, M.; Bošnjaković-Pavlović, N.; Spasojević-de Biré, A.; Vasić, V. Influence of decavanadate on rat synaptic plasma membrane ATPases activity Gen. Physiol. Biophys. 2009, 28, 302.

[27] Ferreira da Silva, J. L.; Minas da Piedade M. F.; Duarte, M. T. Decavanadate: a buildingblock for supramolecular assemblies. Inorg. Chim. Acta 2003, 356, 222-242.

[28] Bogdanović,G. A.; Bošnjaković-Pavlović, N.; Spasojević-de Biré, A.; Ghermani, N. E.; Mioč, U. Low temperature crystal structure, experimental atomic charges and electrostatic potential of ammonium decavanadate hexahydrate $\left(\mathrm{NH}_{4}\right) \mathrm{V}_{10} \mathrm{O}_{28} \bullet 6 \mathrm{H}_{2} \mathrm{O}$. J. Serb. Chem. Soc. 2007, 72, 545-554. 
[29] Bošnjaković-Pavlović, N.; Spasojević-de Biré, A.; Tomaz, I.; Bouhmaida, N.; Avecilla, F.; Mioč, U.; Costa Pessoa, J.; Ghermani, N.E. Electronic Properties of a Cytosine Decavanadate: Toward a Better Understanding of Chemical and Biological Properties of Decavanadates. Inorg. Chem. 2009, 48, 9742-9753.

[30] Frisch, M. J.; Trucks,G. W.; Schlegel, H. B.; Scuseria,G.E.; Robb, M.A.; Cheeseman, J. R.; Montgomery, J. A. Jr.; Vreven, T.; Kudin, K.; Burant, N.et all. Gaussian 03, revision B.04; Gaussian, Inc.: Wallingford. CT, 2004.

[31] Bruker-AXS, SMART (5.625), SAINT (6.02), SADABS (2.03) Data Collection and Processing Software for the SMART System.SiemenSs Analytical X-ray Instruments Inc., Madison 1998.

[32] Blessing, R.H. Outlier Treatment in Data Merging. J. Appl. Crystallogr. 1997, 30, 421426

[33] Altomare, A.; Cascarano, G.; Giacovazzo, C.; Guagliardi, A.; Burla, M. C.; Polidori, G.; Camalli, M.J. SIR92 - a program for automatic solution of crystal structures by direct methods. J. Appl. Crystallogr. 1994, 27, 435-436.

[34] Sheldrick, G.M. SHELXL97 and SHELXS97: Program for the Refinement of Crystal Structures. University of Göettingen, Germany 1997.

[35] Farrugia, L.J. WINGX suite for small-molecule single-crystal crystallography. J. Appl. Cryst. 1999, 32, 837-838.

[36] Burnett, M. N.; Johnson,C.K. ORTEP III. Report ORNL-6895. Oak Ridge National Laboratory, Tenessee, USA, 1996.

[37] For multipole refinement we used the Hansen-Coppens multipole model [38] which represents an analytical description of the asphericity of the atomic charge density distribution. The static deformation density is directly calculated from the multipole refinement. It does not include the thermal motion and could be directly compared to 
theoretical deformation densities. The static density deformation was determined with the STATDENS program [39]. A quantitative investigation of the bonding was performed by means of a topological analysis according to AIM theory [40]. The definition and the classification of the chemical bond in the topological analysis of $\rho$ are based on the existence of a $(3,-1)$ critical point $(\mathrm{CP})$ between neighboring atoms and the properties of charge density at this point. An important function of the electron density is Laplacian and can be obtained from the second derivatives of the total electron density. The topological analysis of the electron density has been carried out using the NEWPROP program [41, 42]. Pertinent refinement parameters (crystal 3. Number of reflexions used in SHELX, all data: 28 757, unique $\left(\mathrm{F}_{0}>4 \sigma \mathrm{F}_{0}\right): 20$ 587; Spherical refinement $\mathrm{R}(\%)$ : 2.88, $\mathrm{R}_{\mathrm{w}}(\%)$ : 3.27, GOF: 1.28,

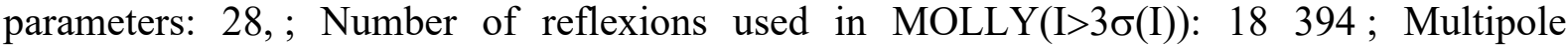
refinement $\mathrm{R}(\%): 2.32$ / $\mathrm{R}_{\mathrm{w}}(\%): 2,34$ / GOF: 0,91 / parameters: 505).

[38] Hansen, N.; Coppens, P. Testing aspherical atom refinements on small-molecule data sets. Acta Crystallogr. 1978, A34, 909-921.

[39] Ghermani, N. E.; Bouhmaida, N.; Lecomte, C. ELECTROS, STATDENS, FIELD+: Computer program to calculate electrostatic properties from high resolution $\mathrm{X}$ ray diffraction. Internal report UMR CNRS 7036, Université Henri Poincaré, Nancy1, France and UMR CNRS 8612, Université Paris XI, France, 1992-2001

[40] R. F. Bader, Atoms in molecules: A Quantum Theory. International Series of Monographs in Chemistry 22, Oxford University Press, Oxford, 1990.

[41] Souhassou, M.; Blessing, B. Topological analysis of experimental electron densities. $J$. Appl. Crystallogr. 1999, 32, 210-217.

[42] Souhassou, M. Atomic Properties from Experimental Electron Densities: Program Newprop-Int. $19^{\text {th }}$ European Crystallographic Meeting, 2000, 195. 
[43] See crystal structure studies references in Table S1, Supplementary Information Material.

[44] See crystal structure studies references in Table S2, Supplementary Information Material. [45] Salam, M. A.; Aoki, K. Interligand interactions affecting specific metal bonding to nucleic acid bases: the tripodal nitrilotriacetato (nta) ligand-system. Crystal structures of [(nta)(adeninium)(aqua)nickel(II)] hydrate, [(nta)(diaqua)nickel(II)]·(cytosinium) hydrate, and $[($ nta)(diaqua)nickel(II)]·(cytosinium) (cytosine) hydrate. Inorg. Chim. Acta. 2000, 311, $15-24$

[46] Kruger,T.; Bruhn, C.; Steinborn, D. Synthesis of [(MeCyt $\left.)_{2} \mathrm{H}\right] \mathrm{I}$ - structure and stability of a dimeric threefold hydrogen-bonded 1-methylcytosinium 1-methylcytosine cation. Org. Biomol. Chem. 2004, 2, 2513-2516.

[47] Muller, J.; Freisinger, E. [(1-Methylcytosine $)_{2}$ H] I, an asymmetric base pair. Acta Crystallogr. 2005, E61, o320-o322.

[48] Eisenstein, M. SCF Deformation densities and electrostatic potentials of purines and pyrimidines. Int. J. Quantum Chem. 1988, 33, 127-158.

[49] Eisenstein, M. Static deformation densities for cytosine and adenine. Acta Cryst. 1988, $B 44,412-416$.

[50] Munshi, P.; Guru Row, T. N. Intra- and intermolecular interactions in small bioactive molecules: cooperative features from experimental and theoretical charge-density analysis. Acta Cryst. 2006, B62, 612-626.

[51] Bene, J. E. Molecular orbital theory of the hydrogen bond. XXX. Water-cytosine complexes. J. Comput. Chem. 1983, 4, 226233.

[52] Chen, L.; Craven, B. Electrostatic properties of $\beta$-cytidine and cytosine monohydrate from Bragg diffraction. Acta Cryst. 1995, B51, 1081-1097. 
[53] Novaković, S.; Fraisse, B.; Bogdanović, G. A.; Spasojević-de Biré, A. Experimental Charge Density Evidence for the Existence of High Polarizability of the Electron Density of the Free Electron Pairs on the Sulfur Atom of the Thioureido Group, $\mathrm{NH}-\mathrm{C}(\mathrm{S})-\mathrm{NH}_{2}$, Induced by $\mathrm{N}-\mathrm{H} \cdots \mathrm{S}$ and $\mathrm{C}-\mathrm{H} \cdots \mathrm{S}$ Interactions.Crystal Growth and Design 2007, 7, 191-195.

[54] Kistenmacher, T. J.; Rossi, M.; Chiang, C. C.; Caradonna, J. P.; Marzilli, L .G. Solution and solid-state studies on the interactions of protonated cytosine salts .4. Asymmetric interbase hydrogen-bonding and interpyrimidine base stacking in triply hydrogen-bonded cytosine complexes - crystal and molecular-structure of bis[1-methylcytosine, 1methylcytosinium] hexafluorosilicate dihydrated Adv. Mol. Relax. Int. Proc, 1980, 17, 113

[55] Ohnet, M.N. ; Spasojević-de Biré, A.; Nguyen, Quy Dao; Schweiss,P.;Braden, M.; Fischer, H.; Reindl, D. Chemical Bonding in Metallaheterocumulene : 1. Neutron diffraction structure on single crystal of pentacarbonyldiethylcyanamidechromium at $110 \mathrm{~K}$. J. Chem Soc, Dalton Trans., 1995, 665-671.

[56] Menoret, C.; Spasojević-de Biré, A.; Nguyen, Quy Dao; Cousson, A.; Kiat, J.M.; Manna, J.; Hopkins, M.D. Chemical Bonding in Methylidyne Complexes: Neutron diffraction study

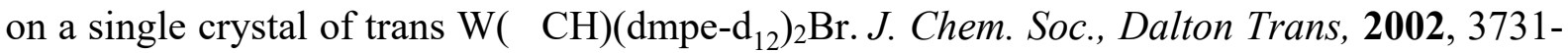
3736. 


\section{Figure captions}

Figure 1. a) step 1, $300 \mathrm{~K}$, b) step 3, $300 \mathrm{~K}$ c) step 6, $180 \mathrm{~K}$ and d) step 7, $100 \mathrm{~K}$ (see table 1 for the step conditions).

Figure 2. Cytosine - cytosinium interactions at $210 \mathrm{~K}$ : a) between cytosinium $\mathrm{A}$ and $\mathrm{A}^{(i)}$ and b) between cytosinium B and the cytosine C. (i) $=-x,-y+1,-z+2$

Figure 3. Static model deformation density map. a) Plane containing the A-A dimer and b) plane containing the B-C.

Figure 4. 3D isodensity surface $\left(0.007 \mathrm{eA}^{-3}\right)$ of the cytosine - cytosinium dimer colored by the electrostatic potential values. Scale in e.Å-1 for theoretical plot and unique scale for experimental plots. a) experimental EP values on B cytosinium; b) experimental EP values on A cytosinium; c) experimental EP values on C cytosine; d) theoretical EP vales on B-C dimmer surface; e) experimental EP values on A-A dimmer surface, the symmetry center is indicated with a black circle; f) and g) experimental EP values on B-C dimer surface (two side views). The first $\mathrm{H} . . . \mathrm{O}$ distance in the $\mathrm{B}-\mathrm{C}$ dimmer is reported (in blue for $\mathrm{B}$ cytosinium, in green for C cytosine).

Figure 5. Cytosine - cytosinium interactions at $100 \mathrm{~K}$ : a) to f) six different dimmers. In contrast of the structure at $210 \mathrm{~K}$, the third character of the label of the atoms have been omitted and the numbering of the cytosine is indicated in the center of each molecules (from 1 to 12$)$. 


\section{Table captions}

Table 1. Experimental diffraction steps preformed on single crystal of $\mathrm{Na}_{3}\left[\mathrm{~V}_{10} \mathrm{O}_{28}\right]$ $\left(\mathrm{C}_{4} \mathrm{~N}_{3} \mathrm{OH}_{5}\right)_{3}\left(\mathrm{C}_{4} \mathrm{~N}_{3} \mathrm{OH}_{6}\right)_{3} \cdot 10 \mathrm{H}_{2} \mathrm{O}$.

Table 2. X-ray diffraction experiments and data reduction details on crystal 2.

Table 3. Selected bond lengths $(\AA)$ with estimated standard deviations in parentheses and comparison with the values retrieved in the CSD [20]

Table 4. Selected distances $\mathrm{d}_{(\mathrm{H}-\mathrm{A})}(\AA)$ of the hydrogen bonds in the cytosine-decavanadate.

Estimated standard deviations are given in parentheses. (i) $=-\mathrm{x},-\mathrm{y}+1,-\mathrm{z}+2$, (iii) $=\mathrm{x},+\mathrm{y},+\mathrm{z}+1$, (iv) $=-x+2,-y,-z+1,($ vi) $=x+1,-y,-z+2,($ vii $)=-x+1,-y+1,-z+1,($ viii $)=x,+y,+z-1$

Table 5. Results of the topological analysis of charge density at $(3,-1)$ bond critical point (BCP) of the molecules of cytosines. $d_{1}$ and $d_{2}$ are the BCP-atom distance $(\AA), \rho\left(r_{c}\right)$ is the electron density at the $\mathrm{BCP}\left(\mathrm{e} \AA^{-3}\right), \nabla^{2} \rho\left(\mathrm{r}_{\mathrm{cp}}\right)$ is Laplacian at the $\mathrm{BCP}\left(\mathrm{e} \AA^{-5}\right)$, e is ellipticity, $\lambda_{1}, \lambda_{2}, \lambda_{3}$, are eigenvalues at the BCP and $\mathrm{H}$ is the total energy density (au).

Table 6. Results of the topological analysis of charge density at $(3,-1)$ bond critical point (BCP) of cytosine molecules.

Table 7. Experimental and theoretical atomic net charge (e) and $\kappa$ values of cytosine molecules. Estimated standard deviations are given in parentheses. ${ }^{1}$ full multipole refinement from [52], ${ }^{2}$ monopole refinement from [52]. 
Table 8. Simplified crystal packing description of the dimers. The atoms used for the originated assignation of the cytosine linked to $\mathrm{O} 2$ or $\mathrm{C} 5$ are in bold. The final assignation (obtained from Table 9) is also reported in the last line according to the $\mathrm{nX}(\mathrm{Y})$ code. $\mathrm{n}=$ label of the cytosine molecule (from 1 to 12 ), $\mathrm{X}=$ final cytosine assignation ( $\mathrm{A}, \mathrm{B}$ or $\mathrm{C}$ ), $\mathrm{Y}=$ originated cytosine assignation (A, B or C). The code is in bold when the originated and the final assignation is different.

Table 9. Pertinent bond angles (C2-N3-C4, N3-C4-C5, N4-C4-C5) (in ${ }^{\circ}$ ) used for discrimination between cytosine and cytosinium. From literature in the first part of the table, from the structure at $100 \mathrm{~K}$ for the second part. $\Delta$ is the bond angles difference in the dimer. The summation of the absolute values of these differences is also reported. The final assignation corresponding to a change from the high structure temperature is indicated in bold. ACITEM [21g], CYTZNC [21b], KESVAG [21b], METSI [56], QOCTUX [21d], GYTYEN [21c], LIWSOA [21j], $300 \mathrm{~K}$ (this work), $210 \mathrm{~K}$ (this work and [28]). 
Scheme 1<smiles>[2H]c1c[nH]c(=O)nc1N</smiles>

cytosine<smiles></smiles>

aminohydroxo<smiles>[2H]Nc1ccc([2H])n(C)c1=O</smiles>

cytosinium<smiles>[2H]N1C=C(C=CN)NC(O)N1</smiles>

iminooxo 
Figures

Figure 1

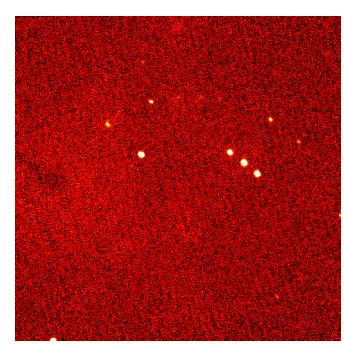

a)

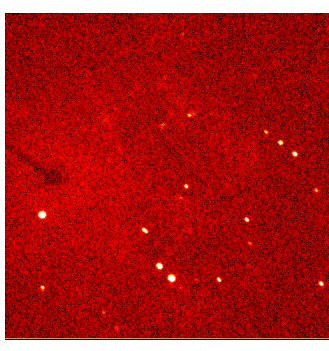

b)

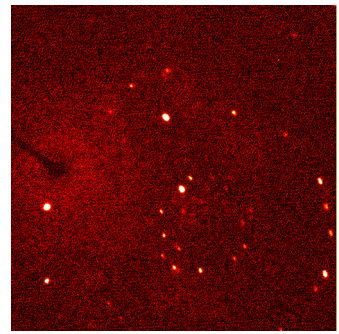

c)

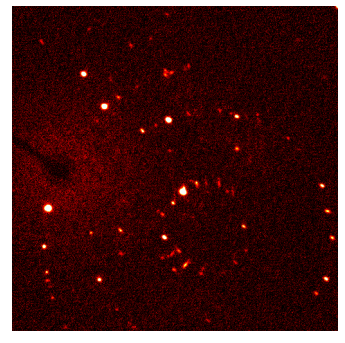

d) 
Figure 2

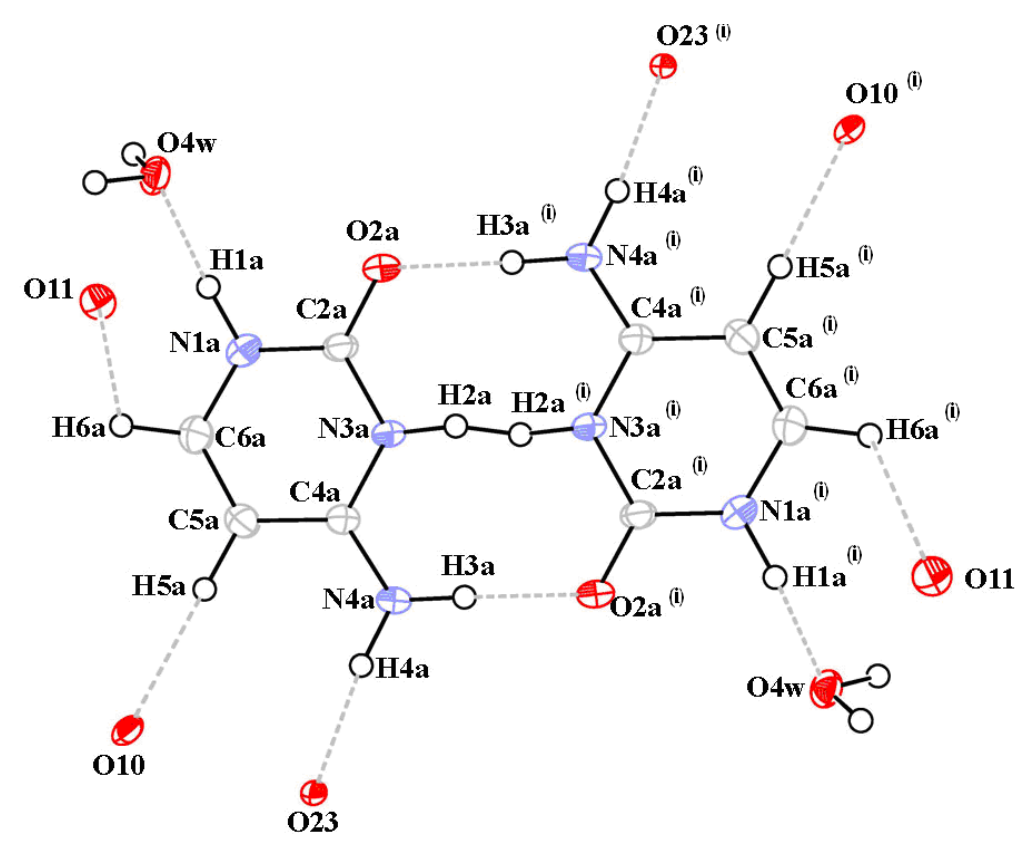

a)

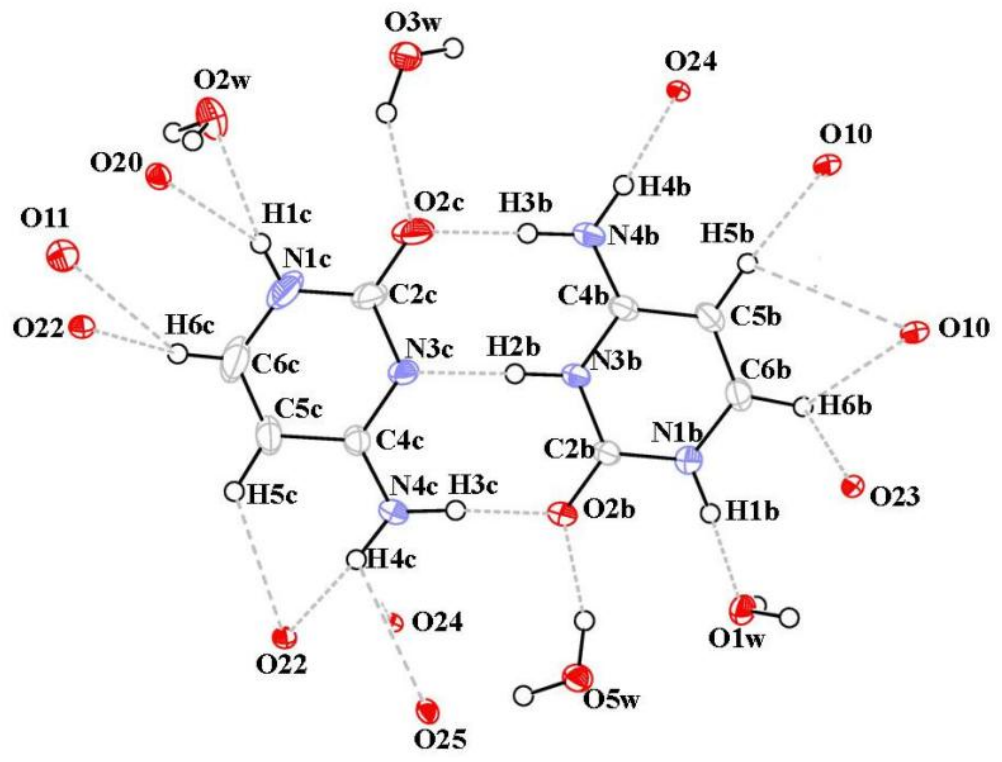

b) 
Figure 3

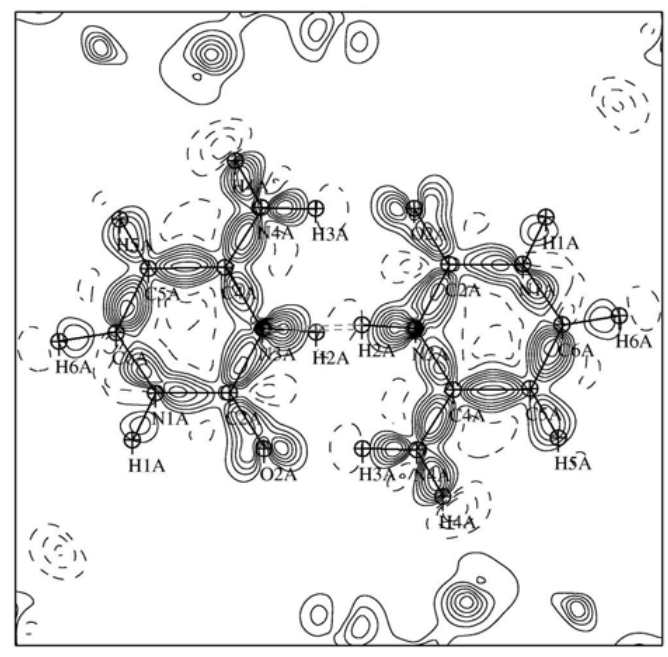

a)

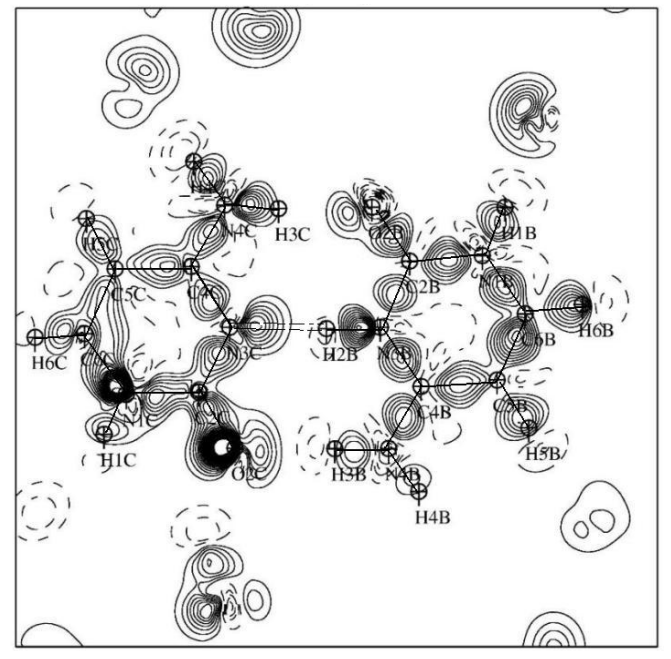

b) 


\section{Figure 4}

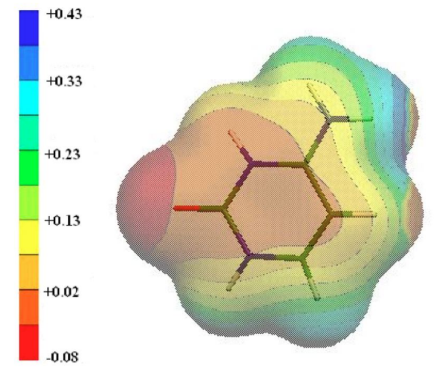

a)
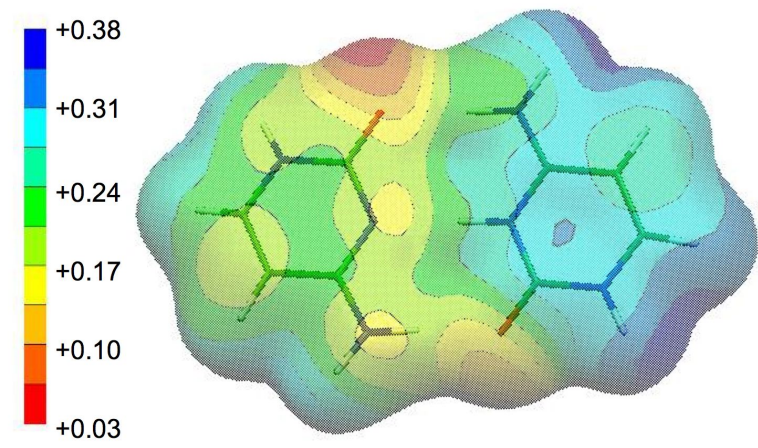

d)
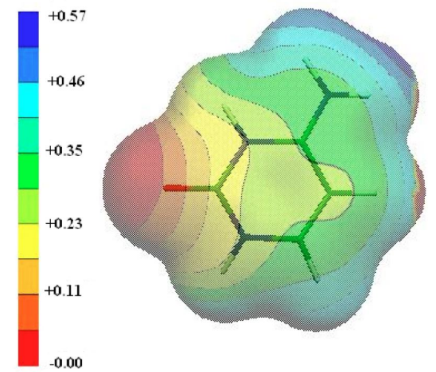

b)
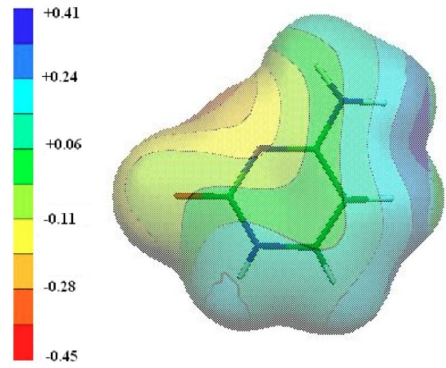

c)

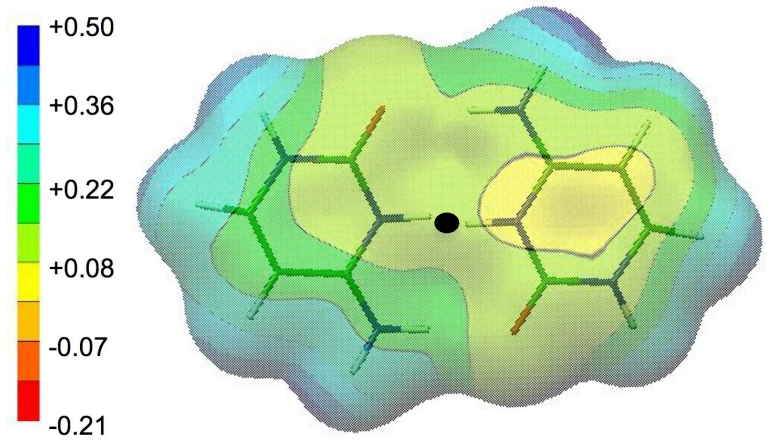

e)

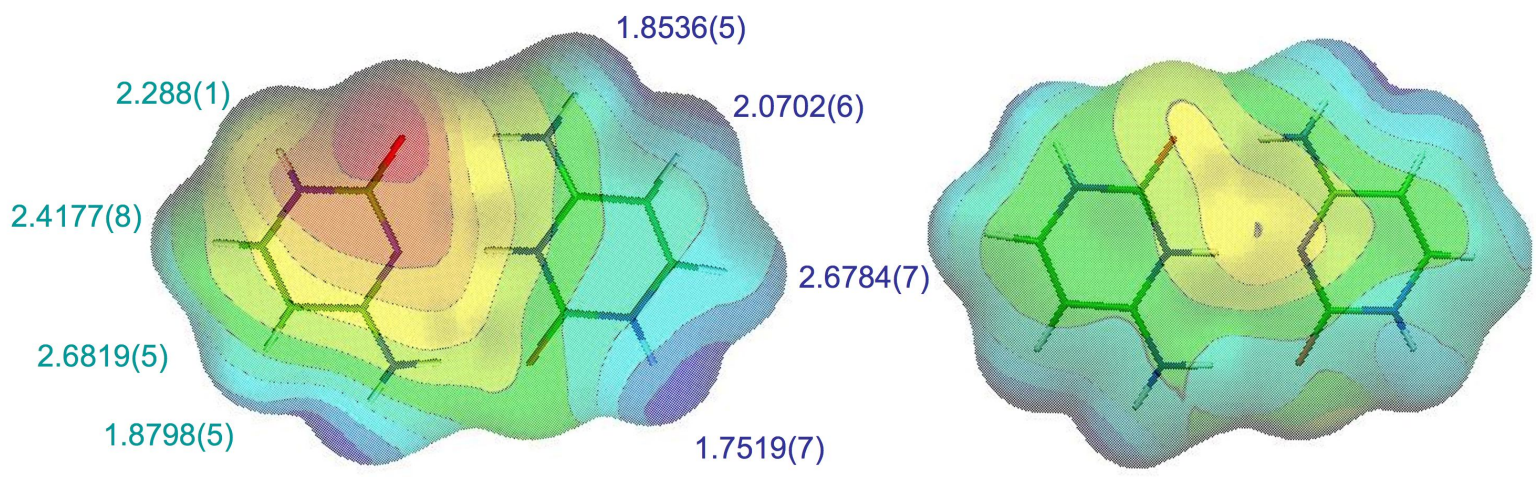

f)

g) 
Figure 5

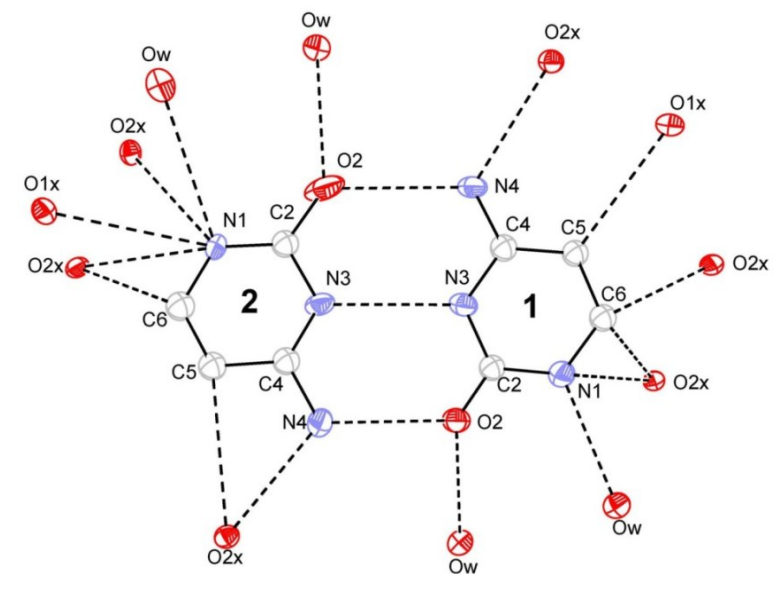

a)

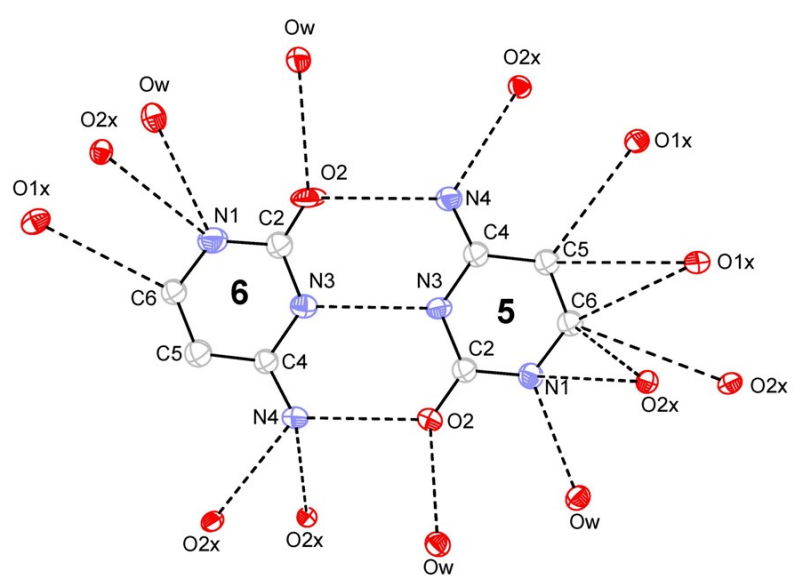

c)

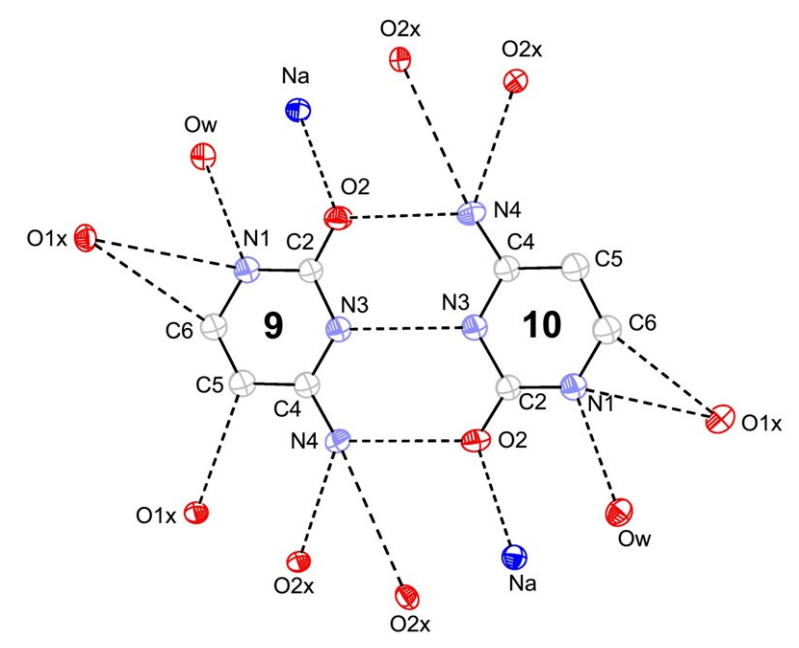

e)

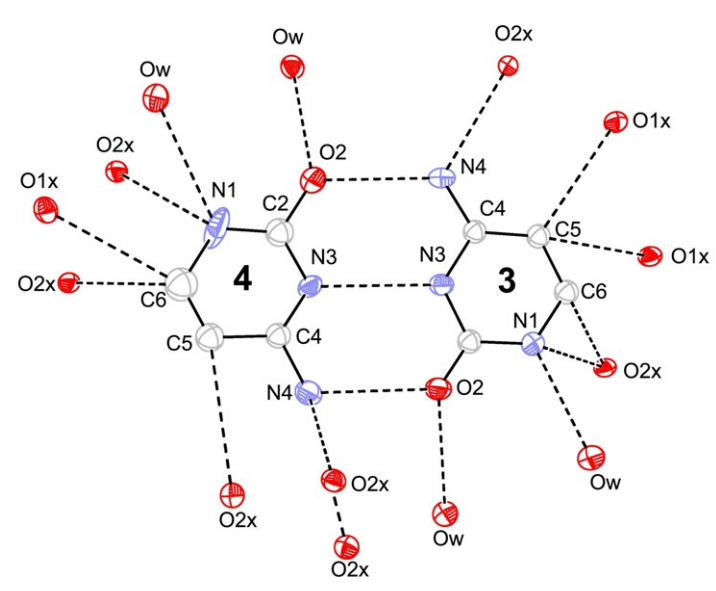

b)

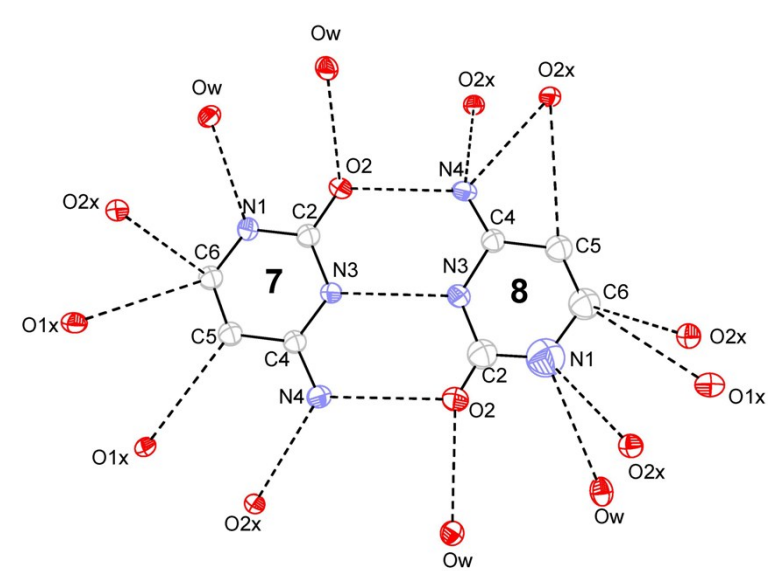

d)

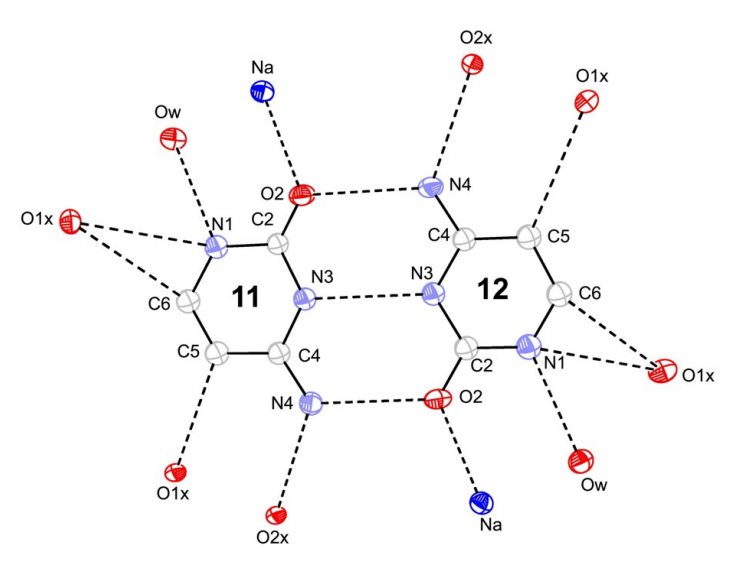

f) 
Table 1.

\begin{tabular}{|c|c|c|c|}
\hline & Crystal & Actions & Observations \\
\hline Step 1 & Crystal 1 & orientation matrix at room temperature & $\mathrm{P} \overline{1}$, all peaks indexed \\
\hline Step 2 & Crystal 1 & ultra freezing at $100 \mathrm{~K}$ & \\
\hline Step 3 & Crystal 1 & orientation matrix at $100 \mathrm{~K}$ & $\mathrm{P} \overline{1}$, some peaks non-indexed \\
\hline Step 5 & Crystal 2 & data collection at room temperature & See Table 2 \\
\hline Step 6 & Crystal 2 & $\begin{array}{l}\text { slow cooling }(10 \mathrm{~K} / \mathrm{h}) \text {, orientation matrix every } \\
30 \mathrm{~K}\end{array}$ & $\begin{array}{l}\mathrm{P} \overline{1} \text {, all peaks indexed until } 210 \mathrm{~K} \text { included, at lower temperature } \\
\text { additional peaks non-indexed }\end{array}$ \\
\hline Step 9 & Crystal 2 & $\begin{array}{l}\text { slow heating }(10 \mathrm{~K} / \mathrm{h}) \text {, orientation matrix every } \\
30 \mathrm{~K}\end{array}$ & $\mathrm{P} \overline{1}$, some peaks non-indexed \\
\hline Step 10 & Crystal 2 & $\begin{array}{l}\text { slow cooling }(10 \mathrm{~K} / \mathrm{h}) \text {, orientation matrix every } \\
30 \mathrm{~K}\end{array}$ & $\mathrm{P} \overline{1}$, some peaks non-indexed \\
\hline Step 11 & Crystal 2 & data collection (high resolution) at $210 \mathrm{~K}$ & See Table 2 \\
\hline Step 12 & Crystal 3 & orientation matrix at room temperature & $\mathrm{P} \overline{1}$, all peaks indexed \\
\hline
\end{tabular}


Table 2

\begin{tabular}{|c|c|c|c|c|}
\hline Chemical formula & \multicolumn{4}{|c|}{$\mathrm{Na}_{3}\left[\mathrm{~V}_{10} \mathrm{O}_{28}\right]\left(\mathrm{C}_{4} \mathrm{~N}_{3} \mathrm{OH}_{5}\right)_{3}\left(\mathrm{C}_{4} \mathrm{~N}_{3} \mathrm{OH}_{6}\right)_{3} \cdot 10 \mathrm{H}_{2} \mathrm{O}$} \\
\hline Temperature $(\mathrm{K})$ & Air, $298 \mathrm{~K}$ & Nitrogen, $210 \mathrm{~K}$ & \multicolumn{2}{|c|}{ Nitrogen, $100 \mathrm{~K}$} \\
\hline Wavelength $(\AA)$ & \multicolumn{4}{|c|}{0.71073} \\
\hline Crystal size: $(\mathrm{mm}) \mathrm{x}(\mathrm{mm}) \mathrm{x}(\mathrm{mm})$ & \multicolumn{4}{|c|}{$0.67 \times 0.16 \times 0.41$} \\
\hline $\mathrm{a}(\AA)$ & $9.9273(2)$ & $9.8547(1)$ & \multicolumn{2}{|c|}{$12.2144(4)$} \\
\hline $\mathrm{b}(\AA)$ & $12.2332(3)$ & $12.2177(1)$ & \multicolumn{2}{|c|}{$14.9129(5)$} \\
\hline $\mathrm{c}(\AA)$ & $13.1147(3)$ & $13.0854(1)$ & \multicolumn{2}{|c|}{$17.6603(3)$} \\
\hline$\alpha\left(^{\circ}\right)$ & $85.968(1)$ & $85.984(1)$ & \multicolumn{2}{|c|}{$106.636(1)$} \\
\hline$\beta\left(^{\circ}\right)$ & $80.082(1)$ & $80.099(1)$ & \multicolumn{2}{|c|}{$103.412(1)$} \\
\hline$\left({ }^{\circ}\right)$ & $70.795(6)$ & $70.928(1)$ & \multicolumn{2}{|c|}{$98.719(1)$} \\
\hline Volume $\left(\AA^{3}\right)$ & $1481.41(6)$ & $1466.68(1)$ & \multicolumn{2}{|c|}{$2914.99(6)$} \\
\hline$[\sin \theta / \lambda]_{\max }\left(\AA^{-1}\right)$ & 0.87 & 1.00 & \multicolumn{2}{|c|}{0.87} \\
\hline Scan width $\left(^{\circ}\right) /$ scan method & $0.2 / \Delta \omega$ scan & $0.15 / \Delta \omega$ scan & \multicolumn{2}{|c|}{$0.2 / \Delta \omega$ scan } \\
\hline $\begin{array}{l}\text { Crystal-to-detector distance }(\mathrm{d}) \\
(\mathrm{cm})\end{array}$ & 4.075 & 4.075 & \multicolumn{2}{|c|}{4.075} \\
\hline Total frames / time per frame (s) & $7200 / 5$ to 10 & $43200 / 3$ to 20 & \multicolumn{2}{|c|}{$5400 / 10$ to 30} \\
\hline Absorption correction & SADABS & SADABS & \multicolumn{2}{|c|}{ SADABS } \\
\hline Total measured reflexions & 53299 & 269448 & \multicolumn{2}{|c|}{77543} \\
\hline $\mathrm{R}_{\text {int }}\left(\mathrm{F}^{2}\right)$ after SADABS & 0.028 & 0.031 & \multicolumn{2}{|c|}{0.056} \\
\hline Cell setting, space group & Triclinic, $\mathrm{P} \overline{1}$ & Triclinic, $\mathrm{P} \overline{1}$ & Triclinic, $\mathrm{P} \overline{1}$ & Triclinic, $\mathrm{P} 1$ \\
\hline $\mathrm{Z}$ & 1 & 1 & 1 & 2 \\
\hline $\begin{array}{l}\text { Program / Number of reflexions } \\
\text { used: all data / unique }\end{array}$ & $\begin{array}{l}\text { SHELX / } 15392 \text { / } 11198 \\
\quad /(\text { F0 > 4sigF0) }\end{array}$ & $\begin{array}{c}\text { MOLLY / / } 16983(\mathrm{I}> \\
3 \sigma(\mathrm{I}))\end{array}$ & $\begin{array}{c}\text { SHELX / } 15155 / \\
13510 /(\mathrm{F} 0> \\
\text { 4sigF0) }\end{array}$ & $\begin{array}{c}\text { SHELX / 45601 / } \\
25198(\text { F0 > 4sigF0) }\end{array}$ \\
\hline $\begin{array}{l}\text { Refinement type: } \mathrm{R}(\%) / \mathrm{R}_{\mathrm{w}}(\%) / \\
\text { GOF / parameters }\end{array}$ & $\begin{array}{c}\text { Spherical / } 5.41 / 8.52 / \\
1.030 / 556\end{array}$ & $\begin{array}{c}\text { Multipole / } 3.63 / 3.46 / \\
1.20 / 505\end{array}$ & $\begin{array}{c}\text { Spherical / 4.73/ } 9.78 \\
\quad / 1.240 / 552\end{array}$ & $\begin{array}{c}\text { Spherical / 10.02 / } \\
13.18 / 1.097 / 1498\end{array}$ \\
\hline Chemical formula & \multicolumn{4}{|c|}{$\mathrm{Na}_{3}\left[\mathrm{~V}_{10} \mathrm{O}_{28}\right]\left(\mathrm{C}_{4} \mathrm{~N}_{3} \mathrm{OH}_{5}\right)_{3}\left(\mathrm{C}_{4} \mathrm{~N}_{3} \mathrm{OH}_{6}\right)_{3} \cdot 10 \mathrm{H}_{2} \mathrm{O}$} \\
\hline Temperature $(\mathrm{K})$ & Air, $298 \mathrm{~K}$ & Nitrogen, $210 \mathrm{~K}$ & \multicolumn{2}{|c|}{ Nitrogen, $100 \mathrm{~K}$} \\
\hline
\end{tabular}




\begin{tabular}{|c|c|c|c|c|}
\hline Wavelength $(\AA)$ & \multicolumn{4}{|c|}{0.71073} \\
\hline Crystal size: $(\mathrm{mm}) \times(\mathrm{mm}) \times(\mathrm{mm})$ & \multicolumn{4}{|c|}{$0.67 \times 0.16 \times 0.41$} \\
\hline $\mathrm{a}(\AA)$ & $9.9273(2)$ & $9.8547(1)$ & \multicolumn{2}{|c|}{$12.2144(4)$} \\
\hline $\mathrm{b}(\AA)$ & $12.2332(3)$ & $12.2177(1)$ & \multicolumn{2}{|c|}{$14.9129(5)$} \\
\hline $\mathrm{c}(\AA)$ & $13.1147(3)$ & $13.0854(1)$ & \multicolumn{2}{|c|}{$17.6603(3)$} \\
\hline$\alpha\left(^{\circ}\right)$ & $85.968(1)$ & $85.984(1)$ & \multicolumn{2}{|c|}{$106.636(1)$} \\
\hline$\beta\left({ }^{\circ}\right)$ & $80.082(1)$ & $80.099(1)$ & \multicolumn{2}{|c|}{$103.412(1)$} \\
\hline$\left({ }^{\circ}\right)$ & $70.795(6)$ & $70.928(1)$ & \multicolumn{2}{|c|}{$98.719(1)$} \\
\hline $\operatorname{Volume}\left(\AA^{3}\right)$ & $1481.41(6)$ & $1466.68(1)$ & \multicolumn{2}{|c|}{$2914.99(6)$} \\
\hline$[\sin \theta / \lambda]_{\max }\left(\AA^{-1}\right)$ & 0.87 & 1.00 & \multicolumn{2}{|c|}{0.87} \\
\hline Scan width $\left(^{\circ}\right) /$ scan method & $0.2 / \Delta \omega$ scan & $0.15 / \Delta \omega$ scan & \multicolumn{2}{|c|}{$0.2 / \Delta \omega$ scan } \\
\hline $\begin{array}{l}\text { Crystal-to-detector distance (d) } \\
(\mathrm{cm})\end{array}$ & 4.075 & 4.075 & \multicolumn{2}{|c|}{4.075} \\
\hline Total frames / time per frame (s) & $7200 / 5$ to 10 & $43200 / 3$ to 20 & \multicolumn{2}{|c|}{$5400 / 10$ to 30} \\
\hline Absorption correction & SADABS & SADABS & \multicolumn{2}{|c|}{ SADABS } \\
\hline Total measured reflexions & 53299 & 269448 & \multicolumn{2}{|c|}{77543} \\
\hline $\mathrm{R}_{\text {int }}\left(\mathrm{F}^{2}\right)$ after SADABS & 0.028 & 0.031 & \multicolumn{2}{|c|}{0.056} \\
\hline Cell setting, space group & Triclinic, $\mathrm{P} \overline{1}$ & Triclinic, $\mathrm{P} \overline{1}$ & Triclinic, $\mathrm{P} \overline{1}$ & Triclinic, $\mathrm{P} 1$ \\
\hline $\mathrm{Z}$ & 1 & 1 & 1 & 2 \\
\hline $\begin{array}{l}\text { Program / Number of reflexions } \\
\text { used: all data / unique }\end{array}$ & $\begin{array}{l}\text { SHELX / } 15392 \text { / } 11198 \\
\text { / (F0 > 4sigF0) }\end{array}$ & $\begin{array}{c}\text { MOLLY / } 16983(\mathrm{I}> \\
3 \sigma(\mathrm{I}))\end{array}$ & $\begin{array}{c}\text { SHELX / } 15155 / \\
13510 /(\mathrm{F} 0> \\
\text { 4sigF0 })\end{array}$ & $\begin{array}{c}\text { SHELX / 45601 / } \\
25198(\mathrm{~F} 0>4 \operatorname{sigF} 0)\end{array}$ \\
\hline $\begin{array}{l}\text { Refinement type: } \mathrm{R}(\%) / \mathrm{R}_{\mathrm{w}}(\%) / \\
\text { GOF / parameters }\end{array}$ & $\begin{array}{c}\text { Spherical / } 5.41 / 8.52 \text { / } \\
1.030 / 556\end{array}$ & $\begin{array}{c}\text { Multipole / } 3.63 \text { / } 3.46 / \\
1.20 / 505\end{array}$ & $\begin{array}{c}\text { Spherical / } 4.73 / 9.78 \\
/ 1.240 / 552\end{array}$ & $\begin{array}{l}\text { Spherical / } 10.02 \text { / } \\
13.18 / 1.097 / 1498\end{array}$ \\
\hline
\end{tabular}


Table 3

\begin{tabular}{|c|c|c|c|c|c|c|}
\hline bond & $\begin{array}{c}\text { Experimental } \\
\text { data at 210 K }\end{array}$ & \multicolumn{2}{|c|}{ Literature data, CSD } & $\begin{array}{c}\text { Experimental } \\
\text { data at 210 K }\end{array}$ & \multicolumn{2}{c|}{ Literature data, CSD } \\
\hline & Cytosinium B & Average data & <min, max $>$ & Cytosine C & Average data & $<$ min, max $>$ \\
\hline C4-N4 & $1.322(1)$ & 1.312 & $1.296-1.327$ & $1.317(1)$ & 1.329 & $1.320-1.342$ \\
\hline C4-C5 & $1.428(1)$ & 1.417 & $1.387-1.430$ & $1.427(11)$ & 1.426 & $1.411-1.440$ \\
\hline C5-C6 & $1.359(1)$ & 1.343 & $1.329-1.354$ & $1.351(2)$ & 1.340 & $1.332-1.353$ \\
\hline C6-N1 & $1.358(1)$ & 1.357 & $1.344-1.372$ & $1.385(2)$ & 1.356 & $1.353-1.361$ \\
\hline N1-C2 & $1.363(1)$ & 1.365 & $1.336-1.381$ & $1.362(2)$ & 1.372 & $1.365-1.382$ \\
\hline C2-N3 & $1.365(1)$ & 1.376 & $1.360-1.394$ & $1.357(1)$ & 1.351 & $1.332-1.364$ \\
\hline N3-C4 & $1.354(1)$ & 1.354 & $1.341-1.362$ & $1.351(1)$ & 1.345 & $1.337-1.353$ \\
\hline C2-O2 & $1.240(1)$ & 1.220 & $1.196-1.246$ & $1.254(2)$ & 1.255 & $1.241-1.274$ \\
\hline
\end{tabular}


Table 4

\begin{tabular}{|c|c|c|c|c|c|c|}
\hline D-H & A & $\begin{array}{c}\mathrm{d}_{(\mathbf{H}-\mathbf{A})} \\
\text { Cytosinium A }\end{array}$ & $\mathbf{A}$ & $\begin{array}{c}\mathrm{d}_{(\mathbf{H}-\mathrm{A})} \\
\text { Cytosinium B }\end{array}$ & $\mathbf{A}$ & $\begin{array}{c}\mathrm{d}_{(\mathrm{H}-\mathrm{A})} \\
\text { Cytosine C }\end{array}$ \\
\hline C5-H5 & $\mathrm{O} 10^{(\mathrm{i})}$ & $2.2430(7)$ & $\mathrm{O} 10^{\text {(vi) }}$ & $2.0702(6)$ & $\mathrm{O} 22^{\text {(iii) }}$ & $2.6819(5)$ \\
\hline C6-H6 & O11 $1^{\text {(vii) }}$ & $2.8154(7)$ & $\mathrm{O} 10$ & $2.6784(7)$ & $\mathrm{O} 11^{\text {(iv) }}$ & $2.4177(8)$ \\
\hline N1-H1 & $\mathrm{O} 4 \mathrm{w}$ & $1.7006(7)$ & O1w & $1.7519(7)$ & $\mathrm{O} 2 \mathrm{w}$ & $2.288(1)$ \\
\hline N4-H4 & $\mathrm{O} 23^{(\mathrm{i})}$ & $1.8678(6)$ & $\mathrm{O} 24^{\text {(viii) }}$ & $1.8536(5)$ & $\mathrm{O} 22^{\text {(iii) }}$ & $1.8798(5)$ \\
\hline Total & & 8,6268 & & 8,3541 & & 9,2674 \\
\hline
\end{tabular}


Table 5.

\begin{tabular}{|c|c|c|c|c|c|c|c|c|c|c|}
\hline $\begin{array}{c}\text { Type of } \\
\text { bond }\end{array}$ & Bond & $d_{1}$ & $d_{2}$ & $\rho_{\left(\mathbf{r}_{c}\right)}$ & $\begin{array}{c}\nabla^{2} \rho_{\left(\mathbf{r}_{\mathrm{c}}\right.} \\
\mathrm{p})\end{array}$ & $\varepsilon$ & $\lambda_{1}$ & $\lambda_{2}$ & $\lambda_{3}$ & $\mathbf{H}$ \\
\hline \multicolumn{11}{|l|}{$\mathrm{C}-\mathrm{C}$} \\
\hline & C5a-C4a & 0.712 & 0.718 & 2.00 & $\begin{array}{l}-18.02 \\
\end{array}$ & 0.34 & -16.66 & -12.46 & 11.09 & -0.44 \\
\hline & C5a-C6a & 0.633 & 0.728 & 2.34 & -22.57 & 0.42 & -19.69 & -13.86 & 10.99 & -0.57 \\
\hline & C5b-C4b & 0.711 & 0.718 & 1.98 & -18.50 & 0.30 & -15.83 & -12.14 & 9.47 & -0.44 \\
\hline & C5b-C6b & 0.520 & 0.839 & 2.16 & -19.29 & 0.32 & -1.63 & -1.56 & 10.09 & -0.50 \\
\hline & $\mathrm{C5c}-\mathrm{C} 4 \mathrm{c}$ & 0.668 & 0.760 & 1.78 & -12.01 & 0.32 & -13.39 & -10.16 & 11.54 & -0.35 \\
\hline & C5c-C6c & 0.661 & 0.691 & 2.01 & -12.34 & 0.43 & -14.97 & -1.52 & 13.16 & -0.42 \\
\hline \multicolumn{11}{|l|}{ C-N } \\
\hline & C2a-N1a & 0.575 & 0.798 & 2.12 & -15.22 & 0.32 & -18.37 & -13.92 & 17.08 & -0.47 \\
\hline & C4a-N3a & 0.617 & 0.735 & 2.20 & -14.90 & 0.21 & -17.78 & -14.74 & 17.62 & -0.50 \\
\hline & C6a-N1a & 0.538 & 0.820 & 2.26 & -21.05 & 0.07 & -18.59 & -17.46 & 14.99 & -0.53 \\
\hline & C2a-N3a & 0.616 & 0.757 & 2.29 & -16.87 & 0.24 & $\begin{array}{l}-19.69 \\
\end{array}$ & -15.86 & 18.69 & -0.53 \\
\hline & C4a-N4a & 0.55 & 0.776 & 2.47 & -24.50 & 0.20 & -21.62 & -18.05 & 15.17 & -0.62 \\
\hline & C2b-N3b & 0.559 & 0.806 & 2.13 & -22.53 & 0.08 & -17.38 & -16.07 & 10.92 & -0.60 \\
\hline & C2b-N1b & 0.535 & 0.829 & 2.30 & -25.85 & 0.14 & -20.07 & -17.59 & 11.80 & -0.57 \\
\hline & C6b-N1b & 0.575 & 0.784 & 2.33 & -23.28 & 0.13 & -19.57 & -17.30 & 13.59 & -0.57 \\
\hline & C4b-N3b & 0.577 & 0.777 & 2.34 & -24.26 & 0.20 & -20.33 & -16.95 & 13.02 & -0.57 \\
\hline & C4b-N4b & 0.558 & 0.766 & 2.57 & -29.96 & 0.24 & -23.46 & -18.98 & 12.48 & -0.68 \\
\hline & C4c-N3c & 0.542 & 0.811 & 2.11 & -15.09 & 0.25 & -16.93 & -13.56 & 15.40 & -0.46 \\
\hline & C2c-N1c & 0.534 & 0.840 & 2.16 & -13.73 & 0.15 & -8.30 & -7.98 & 40.94 & -0.48 \\
\hline & C2c-N3c & 0.546 & 0.812 & 2.18 & -20.05 & 0.05 & -19.08 & -28.21 & 17.24 & -0.51 \\
\hline & $\mathrm{C} 4 \mathrm{c}-\mathrm{N} 4 \mathrm{c}$ & 0.516 & 0.802 & 2.26 & -17.15 & 0.21 & -18.78 & -15.51 & 17.14 & -0.52 \\
\hline \multicolumn{11}{|l|}{$\mathrm{C}-\mathrm{O}$} \\
\hline & C2a-O2a & 0.482 & 0.760 & 2.74 & -23.89 & 0.18 & -27.09 & -22.90 & 26.10 & -0.72 \\
\hline & $\mathrm{C} 2 \mathrm{~b}-\mathrm{O} 2 \mathrm{~b}$ & 0.480 & 0.760 & 2.84 & -31.98 & 0.13 & -27.03 & -23.99 & 19.03 & -0.79 \\
\hline & $\mathrm{C} 2 \mathrm{c}-\mathrm{O} 2 \mathrm{c}$ & 0.537 & 0.736 & 2.58 & -14.84 & 0.04 & -22.19 & -21.23 & 28.57 & -0.63 \\
\hline \multicolumn{11}{|l|}{ H-C } \\
\hline & H5a-C5a & 0.380 & 0.704 & 1.80 & -17.66 & 0.15 & -17.27 & -15.07 & 14.68 & -0.38 \\
\hline & H6a-C6a & 0.403 & 0.677 & 1.93 & -22.50 & 0.02 & -18.09 & -17.79 & 13.48 & -0.43 \\
\hline & H6b-C6b & 0.445 & 0.638 & 1.74 & -17.09 & 0.13 & -8.30 & -7.98 & 40.94 & -0.36 \\
\hline & H5b-C5b & 0.449 & 0.633 & 1.86 & -19.01 & 0.13 & -2.64 & -2.43 & 14.95 & -0.40 \\
\hline & H5c-C5c & 0.308 & 0.778 & 1.58 & -16.37 & 0.09 & -2.09 & -2.08 & 13.04 & -0.31 \\
\hline & H6c-C6c & 0.202 & 0.728 & 1.69 & -22.21 & 0.16 & -23.16 & -19.98 & 20.92 & -0.36 \\
\hline \multicolumn{11}{|l|}{ H-N } \\
\hline & H4a-N4a & & & & & & & & & \\
\hline & H3a-N4a & 0.194 & 0.815 & 1.81 & -27.55 & 0.05 & -28.05 & -26.63 & 27.14 & -0.42 \\
\hline & H1a-N1a & 0.240 & 0.768 & 2.15 & -33.69 & 0.00 & -29.37 & -28.59 & 24.28 & -0.54 \\
\hline & H2b-N3b & 0.158 & 0.856 & 1.49 & -16.75 & 0.04 & -24.17 & -23.33 & 30.75 & -0.29 \\
\hline & H1b-N1b & 0.242 & 0.768 & 2.06 & -31.24 & 0.05 & -28.10 & -26.83 & 23.69 & -0.50 \\
\hline & H3b-N4b & 0.213 & 0.795 & 2.21 & -42.33 & 0.04 & -33.50 & -32.19 & 23.36 & -0.59 \\
\hline & H4b-N4b & 0.240 & 0.770 & 2.24 & -37.97 & 0.04 & -30.95 & -29.89 & 22.86 & -0.59 \\
\hline & H3c-N4c & 0.199 & 0.814 & 1.91 & -27.93 & 0.05 & -9.55 & -9.21 & 43.39 & -0.45 \\
\hline & H4c-N4c & 0.201 & 0.807 & 1.97 & -41.13 & 0.02 & -31.33 & -30.61 & 20.81 & -0.51 \\
\hline & H1c-N1c & 0.162 & 0.690 & 3.00 & -80.55 & 0.05 & -9.55 & -9.21 & 43.39 & -1.02 \\
\hline
\end{tabular}


Table 6.

\begin{tabular}{|c|c|c|c|c|}
\hline & & $\mathrm{C}-\mathrm{C}$ & C-N & C-O \\
\hline & & $<\min , \max >$ & $<\min , \max >$ & $<\min , \max >$ \\
\hline \multirow{3}{*}{$\rho\left(r_{c p}\right)\left(e \AA^{-3}\right)$} & This work & $<1.78,2.33>$ & $<2.11,2.57>$ & $<2.58,2.84>$ \\
\hline & Exp. data [50] & $<2.09,2.39>$ & $<2.36,2.51>$ & 2.95 \\
\hline & Theo. 6-31G ${ }^{* *}$ study [50] & $<2.02,2.28>$ & $<2.20,2.39>$ & 2.57 \\
\hline \multirow{3}{*}{$\nabla^{2} \rho\left(\mathbf{r}_{\mathrm{cp}}\right)\left(\mathrm{e} \AA^{-5}\right)$} & This work & $<-12.01,-22.57>$ & $<-13.73,-29.96>$ & $<-14.84,-31.98>$ \\
\hline & Exp. data [50] & $<-17.46,-22.27>$ & $<-22.23,-25.54>$ & -39.77 \\
\hline & Theo. 6-31G ${ }^{* *}$ study [50] & $<-17.50,-21.57>$ & $<-20.92,-26.62>$ & -19.67 \\
\hline
\end{tabular}


Table 7.

\begin{tabular}{|c|c|c|c|c|c|c|c|c|c|c|}
\hline \multirow[t]{3}{*}{ atom } & \multicolumn{9}{|c|}{ Experimental } & \multirow{3}{*}{$\begin{array}{c}\text { Theoretical } \\
4-31 G^{* *}\end{array}$} \\
\hline & \multicolumn{2}{|c|}{ Cytosinium A } & \multicolumn{2}{|c|}{ Cytosinium B } & \multicolumn{2}{|c|}{ Cytosine $\mathrm{C}$} & \multirow{2}{*}{$\begin{array}{c}\text { [49] } \\
\text { charge }\end{array}$} & \multirow{2}{*}{$\begin{array}{c}{[52]^{1}} \\
\text { charge }\end{array}$} & \multirow{2}{*}{$\frac{[52]^{2}}{\text { charge }}$} & \\
\hline & $\kappa$ & charge & $\kappa$ & charge & $\kappa$ & charge & & & & \\
\hline $\mathrm{C2}$ & $1.09(1)$ & $0.49(6)$ & $1.05(1)$ & $0.72(6)$ & $1.06(2)$ & $0.52(7)$ & 0.16 & $0.12(4)$ & $0.50(3)$ & 0.23 \\
\hline $\mathrm{C} 4$ & $1.051(7)$ & $0.40(6)$ & $1.036(7)$ & $0.49(6)$ & $1.030(7)$ & $0.32(6)$ & 0.13 & $-0.10(5)$ & $0.29(3)$ & 0.17 \\
\hline C5 & $1.051(7)$ & $-0.38(6)$ & $1.036(7)$ & $-0.17(6$ & $1.030(7)$ & $-0.22(6)$ & -0.92 & $0.07(3)$ & $-0.10(3)$ & -0.18 \\
\hline C6 & $1.051(7)$ & $0.10(6)$ & $1.036(7)$ & $0.15(6)$ & $1.030(7)$ & $-0.08(7)$ & 0.67 & $0.09(5)$ & $0.17(4)$ & 0.83 \\
\hline $\mathrm{O2}$ & $1.011(5)$ & $-0.23(6)$ & $0.948(5)$ & $-0.46(6)$ & $0.942(6)$ & $-0.51(8)$ & -0.31 & $-0.37(3)$ & $-0.53(2)$ & -0.44 \\
\hline N1 & $1.000(5)$ & $-0.51(6)$ & $0.967(5)$ & $-0.40(6)$ & $0.974(7)$ & $-0.26(8)$ & -0.67 & $-0.39(5)$ & $-0.39(4)$ & -0.66 \\
\hline N3 & $1.000(5)$ & $-0.51(6)$ & $0.967(5)$ & $-0.63(6)$ & $0.974(7)$ & $-0.87(8)$ & -0.23 & $-0.20(4)$ & $-0.49(2)$ & 0.27 \\
\hline N4 & $1.000(5)$ & $-0.47(6)$ & $0.967(5)$ & $-0.49(6)$ & $0.974(7)$ & $-0.45(7)$ & -0.91 & $0.08(5)$ & $-0.14(5)$ & -1.40 \\
\hline H1 & 1.160 & $0.35(4)$ & 1.160 & $0.39(4)$ & 1.160 & $0.17(5)$ & 0.13 & & & 0.16 \\
\hline $\mathrm{H} 2$ & 1.160 & $0.43(4)$ & 1.160 & $0.41(4)$ & & & & & & \\
\hline H3 & 1.160 & $0.34(4)$ & 1.160 & $0.32(4)$ & 1.160 & $0.24(4)$ & 0.11 & $0.11(3)$ & $0.22(4)$ & 0.15 \\
\hline H4 & 1.160 & $0.35(4)$ & 1.160 & $0.36(4)$ & 1.160 & $0.48(4)$ & 0.11 & $0.07(3)$ & $0.28(2)$ & 0.13 \\
\hline H5 & 1.160 & $0.20(4)$ & 1.160 & $0.14(4)$ & 1.160 & $0.25(4)$ & 0.02 & $-0.02(3)$ & $0.05(2)$ & 0.04 \\
\hline H6 & 1.160 & $0.14(4)$ & 1.160 & $0.17(4)$ & 1.160 & $0.42(4)$ & 0.06 & $0.11(3)$ & $0.05(3)$ & 0.07 \\
\hline
\end{tabular}


Table 8

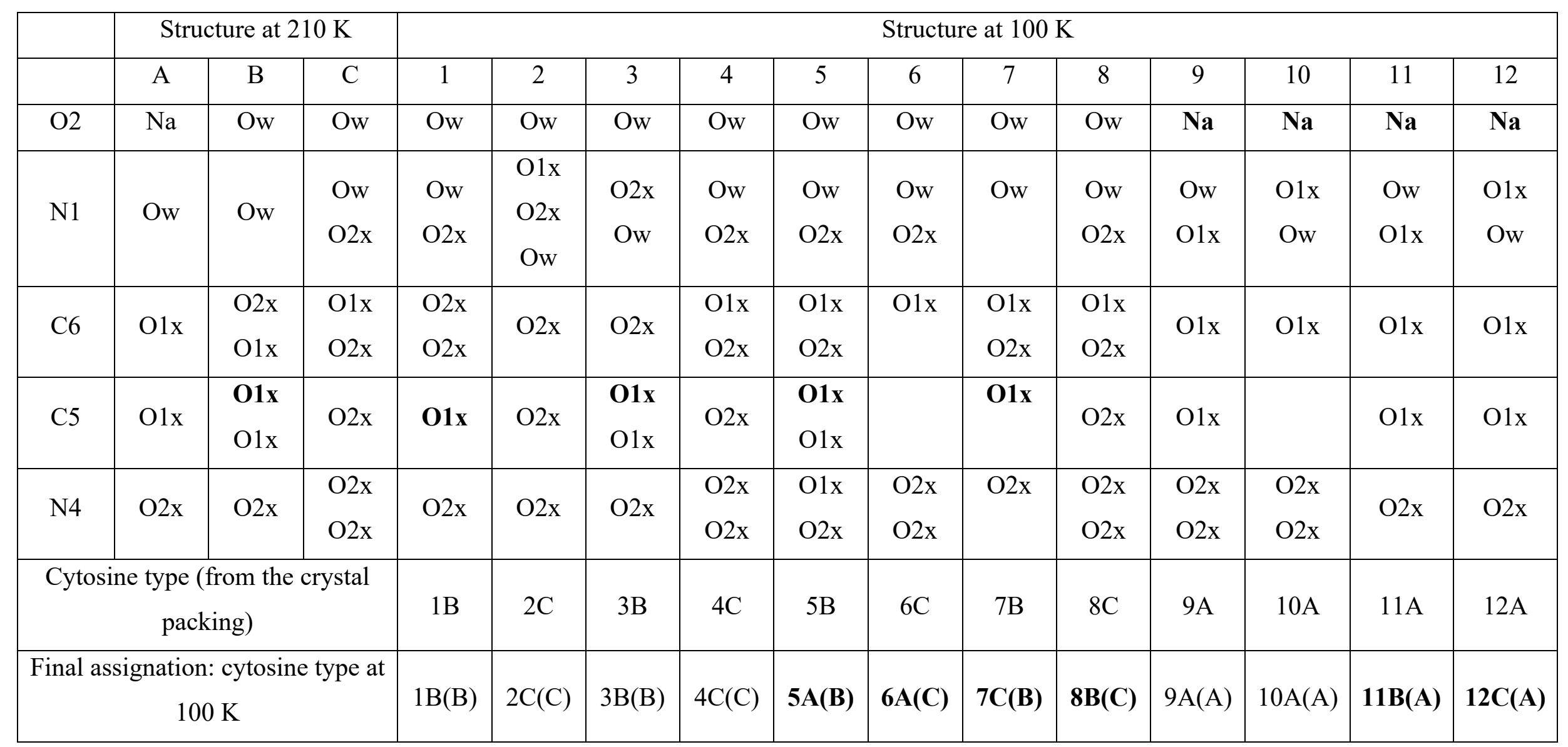


Table 9

\begin{tabular}{|c|c|c|c|c|c|c|c|c|c|c|c|}
\hline & C2-N3-C4 & N3-C4-C5 & N4-C4-C5 & $\mathrm{C} 2-\mathrm{N} 3-\mathrm{C} 4$ & $\mathrm{~N} 3-\mathrm{C} 4-\mathrm{C} 5$ & N4-C4-C5 & $\Delta(\mathrm{C} 2 \mathrm{~N} 3 \mathrm{C} 3)$ & $\Delta(\mathrm{N} 3 \mathrm{C} 4 \mathrm{C} 5)$ & $\Delta(\mathrm{N} 4 \mathrm{C} 4 \mathrm{C} 5)$ & $\sum_{i} \mid \Delta_{i}$ & Assignation \\
\hline ACITEM & 124.34 & 117.38 & 123.82 & 119.24 & 121.34 & 116.99 & 5.1 & -3.96 & 6.83 & 15.89 & B-C \\
\hline CYTZNC & 124.48 & 117.03 & 123.64 & 118.8 & 122.64 & 119.94 & 5.68 & -5.61 & 3.7 & 14.99 & B-C \\
\hline KEVSAG & 123.87 & 118.58 & 123.96 & 118.73 & 123.19 & 120.27 & 5.14 & -4.61 & 3.69 & 13.44 & B-C \\
\hline MECTSI & 124.64 & 117.29 & 124.86 & 120.02 & 120.99 & 121.98 & 4.62 & -3.7 & 2.88 & 11.2 & B-C \\
\hline QOCTUX & 123.28 & 118.53 & 123.64 & 119.78 & 121.04 & 121.59 & 3.5 & -2.51 & 2.05 & 8.06 & B-C \\
\hline $300 \mathrm{~K}$ & 122.00 & 118.87 & 122.74 & 121.47 & 120.27 & 120.94 & 0.53 & -1.4 & 1.8 & 3.73 & B-C \\
\hline $210 \mathrm{~K}$ & 122.15 & 119.13 & 122.23 & 121.88 & 120.5 & 120.56 & 0.27 & -1.37 & 1.67 & 3.31 & B-C \\
\hline GITYEN & 121.49 & 120.85 & 120.42 & 121.12 & 119.27 & 122.04 & 0.37 & 1.58 & -1.62 & 3.57 & A-A \\
\hline LIWSOA & 120.76 & 121.02 & 120.91 & 122.09 & 119.57 & 121.82 & -1.33 & 1.45 & -0.91 & 3.69 & A-A \\
\hline $300 \mathrm{~K}$ & 121.91 & 119.76 & 121.96 & 121.91 & 119.76 & 121.96 & 0 & 0 & 0 & 0 & A-A \\
\hline $210 \mathrm{~K}$ & 121.78 & 119.95 & 121.73 & 121.78 & 119.95 & 121.73 & 0 & 0 & 0 & 0 & A-A \\
\hline $1 \& 2$ & 119.94 & 121.22 & 121.62 & 120.05 & 124.32 & 115.02 & -0.11 & -3.1 & 6.6 & 9.81 & B-C \\
\hline $3 \& 4$ & 122.17 & 119.35 & 123.83 & 119.13 & 125.32 & 115.19 & 3.04 & -5.97 & 8.64 & 17.65 & B-C \\
\hline $5 \& 6$ & 122.98 & 118.01 & 122.43 & 123.05 & 117.95 & 123.81 & -0.07 & 0.06 & -1.38 & 1.51 & $\mathbf{A}-\mathbf{A}$ \\
\hline $7 \& 8$ & 120.4 & 120.14 & 121.54 & 126.36 & 114.47 & 126.67 & -5.96 & 5.67 & -5.13 & 16.76 & C-B \\
\hline $9 \& 10$ & 121.66 & 120.4 & 121.28 & 119.94 & 120.68 & 121.85 & 1.72 & -0.28 & -0.57 & 2.57 & A-A \\
\hline $11 \& 12$ & 125.59 & 117.67 & 122.88 & 119.94 & 120.68 & 121.85 & 5.65 & -3.01 & 1.03 & 9.69 & B-C \\
\hline
\end{tabular}

